\title{
Role of Mineral Nutrition on Root Growth of Crop Plants - A Review
}

\author{
E. Sathiyavani ${ }^{1}$, N.K. Prabaharan ${ }^{1}$ and K. Krishna Surendar ${ }^{2}$ \\ ${ }^{1}$ Department of Agronomy, TNAU, Coimbatore-641 003, India \\ ${ }^{2}$ Department of Crop Physiology, RRS, Paiyur, India \\ *Corresponding author
}

\section{A B S T R A C T}

\begin{tabular}{|l|}
\hline K e y w o r d s \\
Mineral Nutrients, \\
Root Growth, \\
Root \\
Development.
\end{tabular}

Agriculture is going through a profound revolution worldwide due to increasing world demand for food, higher costs of energy and other inputs, environmental pollution problems, and instability of cropping systems. The importance of plant functioning can be realized from the facts that knowledge of mineral nutrition of plants has opened new vistas for fertilizer practices. The detection of deficiencies and toxicity of particular mineral nutrient element has enabled us to make adequate soil amendments and root nutrient absorption for better plant growth. Physiological disorders of many crops such as rice, pulses and oil seeds have been successfully corrected by using minerals. Analysis of plant reveals the presence of a large number of mineral elements. In plant analysis, different mineral nutrient elements are determined even in micro quantities. The estimations are done according to needs either in extracts of fresh plant tissue or by digesting it with nitric acid and perchloric acid. Although plant analysis may be thought of as a method of determining the relative quantities of mineral elements in plants it is at least a crude technique. At present 17 chemical elements such as $\mathrm{N}, \mathrm{P}, \mathrm{K}, \mathrm{Ca}, \mathrm{Mg}, \mathrm{S}, \mathrm{B}, \mathrm{Cl}, \mathrm{Cu}, \mathrm{Fe}, \mathrm{Mn}, \mathrm{Mo}$, and $\mathrm{Zn}$ along with $\mathrm{C}, \mathrm{H}, \mathrm{O}$ are considered as essential elements and each of these essential elements performs one or more specific internal roles in plants. Among the seventeen essential nutrients, some of the nutrients are antagonistic relation to the root growth and some of the nutrients are synergistic relation to the root growth and developments. A less than adequate supply of any one of these essential elements will lead to the metabolic disruptions, including changes in activities of enzymes, rate of metabolic reactions, and concentration of metabolites. In addition to alterations in metabolic patterns, severe deficiencies of individual essential elements also produce a set of characteristic effects in the external appearance of leaves, stems, roots, blossoms, and fruits. In this context, knowledge of factors that affect root development is fundamental to improving nutrient cycling and uptake in soil-plant systems. Roots are important organs that supply water, nutrients, hormones, and mechanical support (anchorage) to crop plants and consequently affect economic yields. In addition, roots improve soil organic matter (OM) by contributing to soil pools of organic carbon (C), nitrogen $(\mathrm{N})$, and microbial biomass. Root-derived soil $\mathrm{C}$ is retained and forms more stable soil aggregates than shoot-derived soil C. Although roots normally contribute only $10-20 \%$ of the total plant weight, a well-developed root system is essential for healthy plant growth and development. Root growth of plants is controlled genetically, but it is also influenced by environmental factors. Mineral nutrition is an important factor influencing the growth of plant roots, but detailed information on nutritional effects is limited, primarily because roots are half-hidden organs that are very difficult to separate from soil. As a result, it is difficult to measure the effect of biotic and abiotic factors on root growth under field conditions. Root growth is mainly measured in terms of root density, length, and weight. Root dry weight is often better related to crop yields than is root length or density. The response of root growth to chemical fertilization is similar to that of shoot growth; however, the magnitude of the response may differ. In nutrient-deficient soils, root weight often increases in a quadratic manner with the addition of chemical fertilizers. Increasing nutrient supplies in the soil may also decrease root length but increase root weight in a quadratic fashion. Roots with adequate nutrient supplies may also have more root hairs than nutrient-deficient roots. This may result in greater uptake of water and nutrients by roots well supplied with essential plant nutrients, compared with roots grown in nutrient-deficient soils. The use of crop species and cultivars tolerant to biotic and abiotic stresses, as well as the use of appropriate cultural practices, can improve plant root system function under favorable and unfavorable environmental conditions. 


\section{Introduction}

Roots are important plant organs. They absorb water and nutrients from the soil and translocate them to plant tops. Roots also give mechanical support to plants and supply hormones that affect many physiological and biochemical processes associated with growth and development. Roots exert control over whole-plant growth and development by controlling the uptake of mineral nutrients. Cytokinins produced in roots are translocated to shoots and participate in the control of leaf protein biosynthesis. In addition, cytokinins may control nitrogen assimilation in the root itself. Oritani (1995) also reported that rice roots synthesize zeatin glucoside, a bound cytokinin, in addition to isopentenyladenine (IP), isopentenyl-adenosine (IPA), trans-zeatin riboside (tZR), and trans-zeatin (tZ), which are free cytokinins in zeatin-related compounds. Zobel (2005a) reported that root system dynamics are instrumental in the maintenance of biological and chemical equilibrium within the soil and modulate changes to soil quality. In addition, genotypes with inherently large root systems have been associated with reduced lodging in cereals and legumes. Soil is knitted together by plant roots, which form complex and structurally diverse reinforcing structures. Near the soil surfaces, fibrous plant roots hold soil aggregates together against the stresses of water and wind. Vigorous root systems are needed for the development of healthy plants and consequently, higher yields. Roots that are left in the soil after crop harvest improve soil organic matter (OM) content and contribute to the nitrogen cycle and microbial activity. All these activities improve soil structure, soil water holding capacity, water infiltration into the soil, as well as reduce soil bulk density and soil erosion, ultimately leading to greater soil productivity.

Processes that are largely controlled or directly influenced by roots and often occur in the vicinity of the root surface are often referred to as rhizosphere processes. These processes may include root turnover, rhizodeposition, root respiration, and rhizosphere microbial respiration that are a result of microbial utilization of rhizodeposits. Rhizosphere processes play an important role in the global $\mathrm{C}$ cycle. Terrestrial ecosystems are intimately connected to atmospheric carbon dioxide levels through photosynthetic fixation of $\mathrm{CO}_{2}$, sequestration of $\mathrm{CO}_{2}$ in plant and soil biomass, and the subsequent release of $\mathrm{C}$ through respiration and decomposition of organic matter. Carbon cycling belowground is increasingly being recognized as one of the most significant components of the ecosystem $\mathrm{C}$ fluxes and pools.

Roots improve soil aggregation, which controls biological and hydrologic properties of the soil. A soil aggregate is a group of primary soil particles that adhere to one another more strongly than to surrounding soil particles. Root materials remain mixed within the soil as they decompose, providing a gum-like material that cements soil particles into aggregates. Root exudation occurs when organic acids either are leaked from the root or are released as a means of interacting with microbes in the rhizosphere. These exudates can influence microbial activity and the subsequent metabolism of root detritus. Mucilages released by the root cap and epidermis link particulate organic residues with mineral fragments.

Microbes in the rhizosphere use plant mucilage as a substrate for growth and secrete their own mucilage, thereby producing mucigel, a mucilaginous material of mixed origin which stabilizes finer aggregates. In addition, in many soils, fungal hyphae are important for stabilizing larger structural units. Finally, allocation of carbohydrates and other C-containing molecules directly to mycorrhizal fungi forms another conduit of $\mathrm{C}$ into the soil as these microbes secrete their own exudates and as their tissues senesce. 
The amount of $\mathrm{C}$ and $\mathrm{N}$ supplied by roots can be significant for maintaining or improving soil organic matter. The organic input from plant roots to the surrounding soil is the principal support of the biological activity and abundance of organisms in the rhizosphere. As much as $7-43 \%$ of the total above-ground and belowground plant biomass can be contributed by roots (Kuo et al., 1997). Roots may have relatively greater influence on soil organic $\mathrm{C}$ and $\mathrm{N}$ levels than the aboveground plant biomass Sanchez et al., 2002). Balesdent and Balabane (1996) reported that corn roots contributed 1.6 times more $\mathrm{C}$ to soil organic $\mathrm{C}$ than did stover. Root-derived $\mathrm{C}$ is retained and forms more stable aggregates than does shootderived $\mathrm{C}$.

Rhizodeposition, such as root exudates, mucilages, and sloughed cells, may be a significant source of soil organic C (Sainju et al., 2005). Helal and Sauerbeck (1987) estimated that the amount of $\mathrm{C}$ released from roots as rhizodeposit could be more than $580 \mathrm{~kg} \mathrm{C} \mathrm{ha}^{-1}$. This rhizodeposition increases microbial activity and influences $\mathrm{N}$ mineralization in the soil. Carbon contribution from corn root biomass and rhizodeposition to soil organic $\mathrm{C}$ can be as much as 1.7-3.5 times greater than from stover (Allmaras et al., 2004).

The environment is seldom optimum for extensive and effective root growth. Canopy conditions that limit photosynthesis reduce shoot growth and limit assimilate translocation to the roots, thus reducing root growth. Root growth is under multi- or polygenic control and is also influenced by environmental factors, including soil temperature, soil moisture content, solar radiation and soil physical, chemical, and biological properties. Most of the root biomass of annual crops is located in the $0-20 \mathrm{~cm}$ soil depth. This may be associated with greater organic matter, nutrients, aeration, and water availability in the top soil layer compared to lower soil depths (Stone et al., 2001). Increased knowledge of root architecture and root development dynamics could help improve crop productivity in agroecosystems. Better under-standing of root architecture and growth dynamics of annual crops may lead to a more efficient use of applied nutrients and water. The study of plant roots is one of the most promising, but least explored, areas of research related to plant growth. The aerial portions of plant species have received greater attention and study, probably because of their conspicuousness and easy access, while the subterranean portions have been neglected because of the difficulty of observing and sampling them and the disruption of root systems when they are removed from soil. Many crop root studies have relied on soil cores and more recently on minirhizotron observations (Zobel, 2005b). The data collected using these methods may not be representative of the crop as a whole. In addition, information about annual field crop root growth dynamics as a function of environmental factors is scattered and often not readily accessible.

The primary objectives of this topic are to review the latest advances in relation to the role of mineral nutrition in the growth and development of roots of annual crops. To make the subject matter as practical as possible, most of the discussion is supported by experimental results. Our approach should enhance understanding on the contribution of roots to total dry matter of crops, to assess the effects of root system size and form on overall crop growth, and to relate the effects of root growth on the environment.

\section{Root-Induced Changes in the Rhizosphere}

Pinton and Varannini (2001) suggested that the soil layer surrounding roots should be termed the ectorhizosphere and the root inside the layer colonized by microorganisms should 
be designated as endorhizosphere. The two areas are separated by the root surface known as rhizoplane (Fig. 1). Growing roots release an appreciable amount of organic components into the rhizosphere. Marschner (1995) reported that three major components released by roots are low-molecular weight organic compounds (free exudates), high-molecular weight gelatinous materials (mucilage), and sloughed-off cells and tissues and their lysates.

The rhizosphere is the soil zone adjacent to plant roots which is physically, chemically, and biologically different than bulk or nonrhizosphere soil. Plants influence the physical (temperature, water availability, and structure), chemical ( $\mathrm{pH}$, redox potential, nutrient concentration, root exudates, $\mathrm{Al}$ detoxification, and allelopathy), and biological properties (microbial association) in the rhizosphere. Their effects include changes in nutrient solubility, transport, and uptake of mineral nutrient, and ultimately plant growth. Major rhizosphere changes are synthesized in Figure 2.

\section{Root system of Cereals and Legumes}

Cereals as well as legume seeds contain relatively large reserves of storage carbohydrates and nutrients which allow the initial root system to grow rapidly to considerable depth. Branching often begins before the leaves have unfolded, with the result that the plant establishes early contact with moist soil (Hoad et al., 2001). Generally, roots are classified into four groups. These groups are the taproot, basal roots, lateral roots, and shootborn or adventitious roots. When plants produce secondary shoots (tillers) or shoot branches which develop roots, these roots are commonly called adventitious roots. To indicate the true origin of these adventitious roots, the term shootborn is sometimes used
(Zobel, 2005a). The primary function of the taproot, basal roots, and adventitious roots is to establish the most optimum framework from which to initiate small lateral roots to effect water and nutrient uptake. The taproot penetrates relatively deeply to ensure an adequate supply of soil water, the basal roots spread out laterally to ensure a structure for lateral roots that take up $\mathrm{P}$ and other nutrients that are less abundant in the lower levels of the soil profile, and to provide a degree of lodging resistance to the plant as it matures and produces seed. For many grasses and other species in which root secondary thickening is not important, the shootborn roots take over the role of the basal roots. The shootborn roots continue to build the framework with larger and larger conducting roots as the plant increases in size. The basal and shootborn roots probably provide little direct uptake of nutrients and water. Besides length and weight, surface area is an important parameter of the root system in crop plants. The form of root systems and their development conditions greatly affect the surface area of roots. The surface area of roots has a high positive correlation with the amount of nutrient absorption. Various studies show that $90-95 \%$ or more of the root length of an intact plant is made up of roots < $0.6 \mathrm{~mm}$ in diameter (Zobel, 2003).

Monocots and dicots typically have different root system structures. Root systems of monocots are fibrous, whereas dicots often have taproots. The fibrous root systems of monocots consist of seminal, nodal, and lateral roots. Seminal roots develop from primordia within seeds and nodal roots develop adventitiously from lower stem nodes. All adventitious roots of stem origin are called nodal roots to distinguish them from other adventitious roots that emerge from the mesocotyl or elsewhere on the plant. Nodal roots are identified by the node number from which they originate. Nodal roots may be 
functional or nonfunctional. Functional nodal roots are defined as roots that have emerged from stem nodes, entered the soil, and developed lateral roots and/or root hairs. Nonfunctional nodal roots are defined as roots that have emerged from aboveground stem nodes and have not entered the soil or produced lateral roots. Initial seminal or nodal roots develop laterals that are classed as roots of the first order, roots that develop from firstorder roots are classed as second-order roots, and additional roots that develop from these laterals are classed as third-order roots, fourthorder roots, etc. Nodal roots are also known as adventitious, coronal, and/or crown roots. Roots of cereals such as rice include mesocotyl, radical (seminal), and nodal or adventitious roots (Yoshida, 1981). Mesocotyl roots emerge from the axis between the coleoptile node and the base of the radical, and they typically develop only when seeds are planted very deep or are treated with chemicals (Yoshida, 1981). Until adventitious roots develop, seedlings must rely on roots which initiate on the subcoleoptile internodes above the seed or seminal roots below the seed. Adventitious roots are important to seedling establishment because they can conduct more water than smaller diameter seminal roots. Adventitious roots may develop as early as 2 weeks after sowing. Seedling survival may increase when seeds are sown at greater soil depths, where greater soil water availability may increase adventitious root development. Tiller roots do not form in cereals until tillers have two to three leaves and until these roots have developed, parent culms must provide nutrients and water. Parent culms may also have to provide hormonal control so essential for tiller survival. Delayed root production by tillers may explain why late tillers often do not survive (Kleeper et al., 1984). Figure 3 shows the radical and adventitious root system of upland rice (Oryza sativa L.) (cereal) and Figure 4 shows the tap root system of dry bean
(Phaseolus vulgaris L.) (legume). In addition to their morphological differences, roots of cereals and legumes have different physiochemical properties. The surface of plant roots has a negative electric charge, mainly due to carboxyl groups in the pectin of the root cell walls. The density of this negative charge is defined as a cation exchange capacity (CEC; Takenaga, 1995). The CEC of cereals such as rice, barley, and corn is typically lower than the CEC of legumes like dry bean and broad bean. Roots with high CEC absorb more divalent cations like $\mathrm{Ca}^{2+}$ and $\mathrm{Mg}^{2+}$ than monovalent cations such as $\mathrm{K}^{+}$and $\mathrm{NH}_{4+}$. On the other hand, roots with lower CEC absorb more monovalent than divalent cations. Hence, in grass-legume mixtures, legumes generally suffer with $\mathrm{K}^{+}$deficiency due to large uptake of this element by grasses.

\section{Rooting Depth and Root Distribution}

Rooting depth and distribution are important traits for absorption of water and nutrients from the soil profile. Rooting depth, that is, the maximum depth that roots reach, is difficult to ascertain in the field. Hsiao et al., (2009) reported that roots typically reach maximum depth about the time when the canopy begins to senesce under nonstress conditions. Gregory (1994) reported that rooting depth in cereals increases until anthesis. Hoad et al., (2001) reviewed the rooting depth literature for cereals and concluded that individual roots of cereal crops can reach a depth of over $2.0 \mathrm{~m}$ under favorable conditions. Soil compaction reduces rooting dept. Martino and Shaykewich (1994) reported that the proportion of roots penetrating the soil is inversely related to the soil penetration resistance.

Ueda (1936) observed that wheat cultivars with relatively great cold resistance had roots that penetrated rapidly into deeper soil layer at early stages of growth. Similarly, Sanders 
and Brown (1978) reported that differences in the yields of indeterminate and determinate soybean varieties mirrored the distribution of their root systems, although the dry weights of their root systems were almost the same. Yamauchi et al., (1987) compared the root system distributions of 13 species of cereals and reported that there was a significant difference among cereals in the distribution and depth of penetration of root systems. Some of the cereals had "concentrated" root systems and others had "scattered" type root systems. Large amounts of organic matter and immobile nutrients are generally found in the upper soil layers. Hence, a major part of the roots of the most crops is concentrated in the upper 0-20 cm soil depth (Gregory, 1994). Application of nitrogen fertilizer to barley caused an accumulation of $90-97 \%$ of the root mass in the top $30 \mathrm{~cm}$ soil layer (Hansson and Andren, 1987). Similarly, Haberle et al. (1996) reported only a few unbranched primary roots below a depth of $25 \mathrm{~cm}$ in fertilized wheat. Differences in root lengths, dry weights of roots at different soil depths, and the extent of rooting at the seedling stage were related to differences in yield and the ability of wheat cultivars to escape drought. Upland rice cultivars, which are more drought tolerant than lowland cultivars, have deeper and more prolific rooting systems (Steponkus et al., 1980). When soil types did not restrict the rooting potential, deep rooting of bean cultivars was positively associated with seed yield, crop growth, cooler canopy temperature, and soil water extraction. Because about $90 \%$ of the total $\mathrm{NH}_{4}, \mathrm{P}$, and $\mathrm{K}$ uptake and root length of flooded rice cultivars occur within the surface $20 \mathrm{~cm}$ of soil, samples collected for routine soil tests should be taken from the top $20 \mathrm{~cm}$ (Teo et al., 1995). Lowland rice plants develop a surface mat of roots in the oxygenated zone near the soil surface soon after application of flood waters. Durieux et al., (1994) reported that more than half of the root length of maize was located in the surface $0-20 \mathrm{~cm}$ depth at all sampling times during a season. Roots of the peanut (Arachis hypogaea L.) cultivar Florunner penetrated to depths up to $280 \mathrm{~cm}$ when grown in a sandy soil, and the most extensive root growth occurred in the top $30 \mathrm{~cm}$. Sharratt and Cochran (1993) reported that $85 \%$ and $95 \%$ of the root mass of barley was located ininterrows of the top 20 and $40 \mathrm{~cm}$ of soil, respectively. Welbank and Williams (1968) also found that nearly $80 \%$ of barley roots occupied the uppermost $15 \mathrm{~cm}$ of soil. A study conducted by Stone and Pereira (1994) of four common bean cultivars and three upland rice cultivars to evaluate rooting depths in an Oxisol showed that $70 \%$ of the roots were concentrated in the top $20 \mathrm{~cm}$ layer and about $90 \%$ were concentrated in the top $40 \mathrm{~cm}$ soil depth of both crops. The presence of these roots in surface soil layers may contribute to large amounts of nutrients measured in the upper $20 \mathrm{~cm}$ of the soil. Using the Claassen-Barber model to predict nutrient uptake by maize grown in silt loam soil, $\quad>90 \%$ of $\mathrm{K}$ and $\mathrm{P}$ uptake occurred in the top $20 \mathrm{~cm}$ soil depth (Schenk and Barber, 1980). Silberbush and Barber (1984) reported that about $80 \%$ of $\mathrm{P}$ and $54 \%$ of $\mathrm{K}$ uptake by soybean was from 0 to $15 \mathrm{~cm}$ depths. Soybean cultivars differ in their rate of downward growth during specific shoot development stages and in their maximum rooting depth on specific. Cultivars selected for rapid taproot elongation rates in a greenhouse trial were found to have greater rooting depths in rhizotron and field trials than cultivars selected for slow taproot elongation (Kaspar et al., 1984).

\section{Root Growth as a Function of Plant Age}

Root development varies with stages of plant growth and development. The most rapid development of corn (Zea mays L.) roots occurs during the first 8 weeks after planting. 
As corn plants age, growth of roots generally increases at slower rates than shoots (Baligar, 1986). After silking, corn root length declines. This decline in root length after silking presumably is due to the high $\mathrm{C}$ demand of grain resulting in enhanced translocation of $\mathrm{C}$ and $\mathrm{N}$ to grain, including some $\mathrm{C}$ and $\mathrm{N}$ that roots would normally obtain.

Peanut (A. hypogaea L.) root length density and root weight density increased at each soil depth increment from planting to 80 days after planting (Ketring and Reid, 1993). These authors reported that roots had penetrated to depths of $120 \mathrm{~cm} \mathrm{40-45} \mathrm{days}$ after planting and spread laterally to $46 \mathrm{~cm}$ in mid-furrow. The $0-15 \mathrm{~cm}$ depth increment had the highest mean root length density, which increased to a maximum of $2.1 \mathrm{~cm} \mathrm{~cm}$ 3 at 80 days after planting (Ketring and Reid, 1993). This meant that peanut roots were established both deeply and laterally in the soil profile early in the growing season. This would be advantageous in drought environments and helpful for water management.

Sunflower (Helianthus annuus L.) rooting depth reached $1.88 \mathrm{~m}$ at the beginning of disk flowering and $2.02 \mathrm{~m}$ at the completion of disk flowering. In a review of depth development of roots with time for 55 crop species (Borg and Grimes, 1986), it was shown that maximum rooting depth for most crop species was generally achieved at physiological maturity. Kaspar et al., (1984) noted that the rate of soybean (Glycine max L. Merr.) root depth penetration reached a maximum during early flowering and declined during seed fill. However, some root growth was observed throughout the reproductive stage until physiological maturity.

Slaton et al., (1990) studied root growth dynamics of lowland rice and found that maximum root growth rates were reached between active tillering and panicle initiation, and maximum root length was reached by early booting. Beyrouty et al., (1987) noted that the most rapid rate of root and shoot growth in flooded rice occurred before panicle initiation, which corresponds to the plant transition between vegetative and reproductive growth. Approximately 77\% and $81 \%$ of total shoot and root biomass, respectively, was achieved before panicle initiation. Following panicle initiation, the length of roots and shoots increased only slightly until harvest (physiological maturity). Beyrouty et al., (1988) also reported that lowland rice root growth was most rapid during vegetative growth, with maximum root length occurring at panicle initiation. Root length either plateaued or declined during reproductive growth.

Fageria and Santos (2011) studied the root and shoot growth of lowland rice during its growth cycle (Figure 5). Root dry weight increased in a quadratic fashion with the advancement of plant age from 19 to 120 days, but shoot dry weight increased linearly during the growth cycle. Development of the root system was slow during the first 40 days after sowing and then it increased almost linearly until physiological maturity. The slow increase in root dry weight early in the growth cycle may be associated with low translocation of photosynthetic materials due to low leaf area (Fageria, 2007). When there is a low amount of photosynthetic product, a major part goes to the shoot, and very little is translocated to the roots (Fageria, 1992). Root growth generally parallels shoot growth in crop plants. When a large amount of nutrients, especially $\mathrm{N}$, is supplied to leaves from roots, photosynthesis remains high during maturation, which secures the supply of carbohydrates to roots. Hence, the activities of roots and shoots are mutually dependent. 


\section{Root-Shoot Ratio}

The partitioning of photoassimilate between roots and shoots has frequently been analyzed as a balance between root and shoot activity. Different plant species may have different patterns for photosynthate transportation and allocation to shoot and root. There is an interdependence of shoot and root for growth and development. The shoot relies on the root for water and nutrients, while the roots depend on the shoot for carbohydrates (Hoad et al., 2001). The terms "shoot" and "root" are used here in a botanical sense and refer, respectively, to the entire aerial and subterranean portions of higher seed plants (Aung, 1974). In the early part of the twentieth century, shoot-root ratios were used rather extensively to characterize plant response to imposed nutritional changes. Root growth is closely related to the whole plant growth. This relationship is called "allometry" or relative growth. Root dry weight is related to the total dry weight of a plant using the following equation (Yoshida, 1981):

$$
W_{\mathrm{R}}=H W_{\mathrm{T}}^{h} \text {, }
$$

Where $\mathrm{W}_{\mathrm{R}}$ is the root dry weight, $\mathrm{W}_{\mathrm{T}}$ is the total dry weight (shoot dry weight $\mathrm{p}$ root dry weight), and $\mathrm{H}$ and $\mathrm{h}$ are constants. The shoot:root biomass ratio changes during ontogeny, generally becoming high as the plant approaches flowering, and stabilizing after flowering. Shoot-to-root ratios of common bean, rice, wheat, and cowpea increased as plants advanced in age (Fageria, 1992). Increases in shoot-to-root ratios indicate that shoots have a higher priority for photosynthate accumulation than roots. If shoot-root ratios decrease with time, roots have preferential utilization of photosynthates under the existing plant growth conditions. A relatively high conservation of photoassimilate in shoots may increase the plant's photosynthetic leaf area while decreasing root biomass and the plant's capacity for water and nutrient uptake (Werf, 1996). Environmental stresses increase the relative weights of roots compared to shoots. Decrease in the availability of N, P, or water increased root-shoot ratios of perennial ryegrass (Lolium perenne L.) (Davidson, 1969). Although deficiencies of many mineral elements influence plant growth and rootshoot relationships, invariably water and $\mathrm{N}$ deficiency limit shoot growth the most. Rootshoot ratios of 28-day-old maize plants were $0.27,0.15$, and 0.18 at volumetric soil moisture contents of $0.22,0.27$, and $0.32 \mathrm{~m}^{3}$, respectively (Mackay and Barber, 1985). When plants are $\mathrm{N}$-deficient, relatively more photosynthate is used by roots as they develop greater length to aid the plant in obtaining more N. In general, when low nutrient levels do not reduce maize grain yield by more than $20 \%$, addition of $\mathrm{N}$ will reduce total root weights even though shoot weights increase. Champigny and Talouizte (1981) reported that under $\mathrm{N}$ deprivation, translocation of photoassimilates from shoots to roots increased because of increased sink strength of roots compared to shoot sinks. In an experiment with 18-day-old wheat seedlings deprived of $\mathrm{N}$ for 7 days, soluble sugar contents in roots were higher than in the corresponding roots of seedlings grown continuously with complete nutrient solutions. Similarly, root-shoot ratios of maize plants were higher when grown with low soil $\mathrm{N}$ compared to adequate $\mathrm{N}$ (Eghball and Maranville, 1993). Soil salinity is another important soil chemical property that influences shoot-root ratios. The depressing effect of salinity on root growth is generally less severe than its effect on shoot growth. Shalhevet et al. (1995) summarized the results of 10 experiments relating shoot and root growth to salinity. In all the experiments, the root and shoot responses were evaluated by measuring fresh or dry weights at the end of the experimental periods. All the 10 experiments produced 
either the same or stronger growth responses of shoots than roots because of the imposed osmotic potential. However, Slaton and Beyrouty (1992) observed shoot-root ratios of rice remained constant as a result of a functional equilibrium in which shoot growth was proportional to root growth. Partitioning of photosynthates and their effects on dry matter distribution is influenced by several environmental factors such as low temperature, drought, and mineral nutrient deficiency. The mineral nutrients $\mathrm{P}$ and $\mathrm{N}$ exerted pronounced influences on photosynthate and dry matter partitioning between shoots and roots (Costa et al., 2002). Phosphorus and N-deficient plants usually produce proportionately more dry matter to roots than shoots, compared with unstressed plants. This probably results from higher export rates of photosynthate to roots in deficient plants. Leaf expansion is highly sensitive to low tissue $\mathrm{P}$ concentrations, producing higher concentrations of sucrose and starch in P-deficient leaves because of reduced demand (Fredeen et al., 1989).

Thus, roots become more competitive for photosynthates than shoots, which leads to higher export of carbohydrates to roots with correspondingly lower shoot-root ratios. Cakmak et al., (1994) reported that dry matter partitioning between shoots and roots of common bean was affected differently by low supplies of $\mathrm{P}, \mathrm{K}$, and $\mathrm{Mg}$. Although total dry matter production was somewhat similar in $\mathrm{P}-, \mathrm{K}-$, and $\mathrm{Mg}$-deficient plants, $\mathrm{K}-$ and especially $\mathrm{Mg}$-deficient plants had greater than normal shoot-root ratios, while $\mathrm{P}$ deficient plants had smaller than normal shoot-root ratios (Cakmak et al., 1994). Shoot-root dry weight ratios were 1.8 in $\mathrm{P}$ deficient, 4.9 in control, 6.9 in K-deficient, and 10.2 in $\mathrm{Mg}$-deficient plants. Upland rice usually has high root/shoot weight ratios than lowland rice, an adaptation improving access to soil water (Dingkuhn and Kropff, 1996).

\section{Root Growth Versus Crop Yield}

Roots are responsible for absorption of water and nutrients which are important resources affecting crop yields. In addition, roots improve soil organic matter content and biological activity in the rhizosphere. Root length and root dry weight are standard root parameters that are measured in many studies, largely because they are more easily determined than other root system properties (Gregory, 1994). Barber and Silberbush (1984) studied the relationship between root length and soybean yield and concluded that yield was significantly related to total root length at the R6 (full seed) stage. These authors concluded that root growth is important in determining the nutrient supply to the shoot which, in turn, affects crop yield. Similarly, Thangaraj et al., (1990) reported that root length density of lowland rice at flowering was directly proportional to grain yield. Leon and Schwang (1992) used the grid intercept method to evaluate differences in total root length between cultivars of oats and barley and found that yield stability was correlated with root system length. The first author studied the relationship between maximum root length and root dry weight and grain yield of upland rice.Grain yield increased in a quadratic fashion with increasing root length or root dry weight, and root dry weight was a better predictor than root length of yield.

\section{Genotypic Variation in Root Growth}

Variability in root growth among crop species and among genotypes of the same species is widely reported in the literature (Kujira et al., 1994). This variability can be used in improving the yield of annual crops by incorporating vigorous root growth into desirable cultivars. Vigorous root growth is especially important when nutrient and water stress are significant. Ludlow and Muchow 
(1990), in their review of traits likely to improve yields in water-limited environments, place a vigorous rooting system high in their list of properties to be sought. O'Toole and Bland (1987) reviewed genotypic variation in root growth of annual crops and reported significant differences in rooting depths, maximum root length, and distribution pattern in the soil profile. Yoshida and Hasegawa (1982) reported rooting depth differences among genotypes of wheat (Triticum aestivum L.) and rice, respectively. Similarly, Brown et al., (1987) also reported differences in rooting depths of corn and barley (Hordeum vulgare L.), respectively. Similar variability exists in dicotyledonous species where most work has been undertaken on legumes, including dry bean, soybean, chickpea (Cicer arietinum L., peanut, and white clover (Trifolium repens L). Hamblin and Tennant (1987) compared root growth and water uptake of wheat and lupin (Lupinus albus L.) and Gregory and Brown (1989) did similar work with barley and chick pea.

These authors concluded that there were differences between the species in the root length necessary to extract water, and the rate of water extraction was greater in legumes than in cereals. Fageria (1991) studied root dry weight of the Brazilian upland rice cultivars IAC 47 and the International Rice Research Institute (IRRI) cultivar IR 43 and concluded that root dry weight of Brazilian cultivars was almost double that of the IRRI cultivar during the entire growth cycle. Xiaoe et al., (1997) reported that hybrid rice has a more vigorous root system, larger panicle, and more grains per panicle than traditional rice cultivars.

The genotypic variability in the root growth of annual crops has been used to identify superior genotypes for drought-prone environments (Gregory, 1994). Gregory and Brown (1989) reviewed the role of root characters in moderating the effects of drought and concluded that roots may have a direct effect, by increasing the supply of water available to the crop, or an indirect effect by changing the rate at which the supply becomes available. Where crops are grown on deep soils and water is stored throughout the whole soil profile, the depth of rooting has a major influence on the potential supply of water (Gregory, 1994). Rain may replenish the upper soil during the season, but later growth and grain filling in many crops are accomplished during periods of low rainfall when soil moisture stored deep in the profile must be utilized. Sponchiado et al., (1989) reported that in dry bean, drought avoidance results from root growth and soil water extraction deep in the profile. Atkinson (1990) reported significant variation in the speed of root penetration, specific root length, branching pattern, root density, total root mass, and root hair development of 25 spring barley cultivars. Information reported in the literature on old and new cereal cultivars indicates that more modern cultivars are more responsive than older cultivars to high nutrient availability (Haberle et al., 1995), although they tend to have a lower root fraction (Wahbi and Gregory, 1995). Root physiological characteristics also differ among cultivars and can affect processes like nutrient acquisition (Hoad et al., 2001). The rate of uptake of nutrient per unit root length depends on the nutrient availability but also varies considerably among cultivars (Hoad et al., 2001).

\section{Mineral Nutrition Versus Root Growth}

There are 17 nutrients essential for plant growth and development and these are carbon (C), hydrogen (H), oxygen (O), nitrogen $(\mathrm{N})$, phosphorus $(\mathrm{P})$, potassium $(\mathrm{K})$, calcium $(\mathrm{Ca})$, magnesium $(\mathrm{Mg})$, sulfur $(\mathrm{S})$, zinc $(\mathrm{Zn})$, copper $(\mathrm{Cu})$, manganese $(\mathrm{Mn})$, iron $(\mathrm{Fe})$, boron (B), molybdenum (Mo), chlorine $(\mathrm{Cl})$, and nickel (Ni). Among these nutrients, plants take $\mathrm{C}, \mathrm{H}$, and $\mathrm{O}$ from air and soil 
water and the remaining from the soil solution. About $95 \%$ of the plant weight is $\mathrm{C}$, $\mathrm{H}$, and $\mathrm{O}$, and the remaining $5 \%$ is the other 14 nutrients. The $\mathrm{C}, \mathrm{H}, \mathrm{O}, \mathrm{N}, \mathrm{P}, \mathrm{K}, \mathrm{Ca}, \mathrm{Mg}$, and $\mathrm{S}$ are required by plants in large amounts and for this reason are known as major or macronutrients. The remaining nutrients, $\mathrm{Zn}$, $\mathrm{Cu}, \mathrm{Mn}, \mathrm{Fe}, \mathrm{B}, \mathrm{Mo}, \mathrm{Cl}$, and $\mathrm{Ni}$, are classified as micronutrients because they are required in small amounts by plants (Fageria et al., 2002). Among the micronutrients, $\mathrm{Cl}$ is also absorbed by plants in large amounts, but it is needed in only small amounts, and $\mathrm{Cl}$ deficiency is rarely observed in crop plants. All the 17 nutrients are equally important for plant growth. If any of these nutrients is limiting in the growth medium, plant growth will be reduced. An example is given in Fig. 8 , where at an adequate fertility level, the relative dry weight of dry bean was $100 \%$. When essential nutrients were omitted from the soil or were not applied, growth was reduced, but the amount of reduction depended on the nutrient. The impacts of deficiencies on growth were in the order of $\mathrm{P}$ $>\mathrm{Ca}>\mathrm{Mg}>\mathrm{N} 1 / 4 \mathrm{~K}>\mathrm{S}$ among macronutrients and $\mathrm{B}>\mathrm{Zn}>\mathrm{Cu}>\mathrm{Fe}>\mathrm{Mn}>$ Mo among micronutrients. Similarly, the influence of $\mathrm{N}, \mathrm{P}$, and $\mathrm{K}$ on shoot and root growth of dry bean is shown in Fig. 9. Both shoot and root growth were significantly reduced when $\mathrm{N}, \mathrm{P}$, or $\mathrm{K}$ were omitted from the growth medium.

Root growth of wheat, upland rice, and corn with the addition of $\mathrm{N} \mathrm{p} \mathrm{P} \mathrm{p} \mathrm{K} \mathrm{and} \mathrm{with} \mathrm{the}$ omission of these nutrients from the growth medium. Root growth of these three crop species was decreased in the absence of $\mathrm{N}, \mathrm{P}$, and $\mathrm{K}$ in the soil. A significant amount of variation exists, both within and among crop species, in nutrient acquisition and use. This variability reflects differences in root morphology and mechanisms that either aid or prevent ion movement into the root (Gabelman et al., 1986).

\section{Nitrogen}

Nitrogen is one of the most yield-limiting nutrients in crop production in most agroecosystems. Nitrogen plays numerous key roles in plant biochemistry, including being an essential constituent of enzymes, chlorophyll, nucleic acids, storage proteins, cell walls, and a vast array of other cellular components (Harper, 1994). Consequently, a deficiency of $\mathrm{N}$ in crop plants profoundly influences plant growth, development, and yield. The recovery of applied $\mathrm{N}$ with chemical fertilizers is lower than $50 \%$ for most annual crops. The low recovery of $\mathrm{N}$ is associated with loss of this element by leaching, denitrification, volatilization, incorporation into soil micro-organisms, and soil erosion (Fageria and Baligar, 2005). To improve the efficiency of $\mathrm{N}$ uptake and use by crop plants, root systems play an important role.

Root morphology is influenced by the amount of $\mathrm{N}$ fertilizer applied (Eghball et al., 1993) and factors such as temperature and soil mechanical impedance. Eghball et al., (1993) showed that $\mathrm{N}$ stress in corn reduced root branching. Similarly, Maizlish et al., (1980) showed greater root branching in corn with increasing levels of applied fertilizer N. Costa et al., (2002) reported that greater root length and root surface area were obtained at an $\mathrm{N}$ fertilizer rate of $128 \mathrm{~kg} \mathrm{~N} \mathrm{ha}^{-1}$ compared with either the absence of fertilizer $\mathrm{N}$ or the higher rate of $255 \mathrm{~kg} \mathrm{~N} \mathrm{ha}{ }^{-1}$. Nitrogen fertilizer improves root growth in soils having low-OMcontent (Gregory, 1994). Nitrogen fertilization may increase crop root growth by increasing soil $\mathrm{N}$ availability (Garton and Widders, 1990). Sainju et al., (2001) observed that tomato (Lycopersicon esculentum Mill.) root growth was greater with hairy vetch and crimson clover cover crops and $90 \mathrm{~kg}$ $\mathrm{N}$ ha $^{-1}$ than with no cover crops or $\mathrm{N}$ fertilization. Nitrogen also improves 
production of lateral roots and root hairs, as well as increasing rooting depth and root length density deep in the profile. Hoad et al., (2001) reported that surface application of nitrogen fertilizer increases root densities in the surface layers of the soil.

Nitrogen fertilization can increase root length and root surface area and decrease root mass per unit area of corn (Costa et al., 2002). It is well known that roots tend to proliferate in nutrient enriched soil zones (Qin et al., 2005). Russell (1977) refers to this as a compensatory response. The results of pot experiments showed that corn roots were longer and thinner in zones that were rich in N (Durieux et al., 1994). Root mass was less affected by $\mathrm{N}$ than root length, but the effect may depend on the stage of maturity of the crop (Baligar et al., 1998). Higher rates of application of $\mathrm{N}$ reduced root growth and depth of rooting in wheat (Comfort et al., 1988) and reduced root:shoot ratio in rye (Brouwer, 1966). In corn, the primary root system was $16 \%$ thicker when $\mathrm{NH}_{4 \mathrm{p}}-\mathrm{N}$ was applied rather than $\mathrm{NO}_{3}-\mathrm{N}$. The $\mathrm{NH}_{4 \mathrm{p}}-\mathrm{N}$ treatment also increased the diameters of lateral and first- and second-order nodal roots (Anderson et al., 1991). Baligar et al., (1998) reported that relative dry weights of roots of rice, dry bean, corn, and soybean were reduced by $38 \%, 56 \%, 35 \%$, and $11 \%$, respectively, when $\mathrm{N}$ was omitted from a complete fertilizer. Nitrogen deficiency also reduces branching and root hairs in cereals and legumes (Baligar et al., 1998). The increasing the $\mathrm{N}$ fertilizer rate from 0 to $400 \mathrm{mg} \mathrm{kg}^{-1}$ increased root dry weight of upland rice in a linear fashion in Brazilian Oxisol, with the rate of $\mathrm{N}$ fertilizer explaining $59 \%$ of the variation in root weight. Nitrogen fertilization increases production of thinner roots with fine root hairs (personal visual observation). Data in Table 1 show root length and root dry weight of 20 upland rice genotypes grown on a Brazilian Oxisol. These two traits were significantly influenced by $\mathrm{N}$ rate and genotype treatments. A significant interaction between genotypes and $\mathrm{N}$ rates was found for root growth because some genotypes were highly response to the $\mathrm{N}$ application while others were not Nitrogen sources also affect root growth in upland rice.

Root dry weight increased in a quadratic exponential fashion with the application of $\mathrm{N}$ in the range of $0-400 \mathrm{mg} \mathrm{kg}^{-1}$ of soil. In the case of urea, maximum vroot dry weight was obtained with $281 \mathrm{mg} \mathrm{N} \mathrm{kg}^{-1}$ of soil. Figure 13 show how the root growth of upland rice is affected by application of urea and ammonium sulfate in the Brazilian Oxisol.

Ammonium sulfate produced more vigorous root systems, especially at higher $\mathrm{N}$ rates, than urea, perhaps because upland rice is highly tolerant to soil acidity and ammonium sulfate reduces soil $\mathrm{pH}$ more than urea. Fageria (2009) reported that upland rice can tolerate up to $70 \% \mathrm{Al}$ saturation in the soil. The timing of nitrogen application can also influence the root growth of crop plants (Table 2).

The treatment $T_{3}$, which produced maximum grain yield, also produced minimum root length; treatment $\mathrm{T}_{2}$ which produced minimum grain yield produced maximum root length. There was a negative association between root length and grain yield $\left(\begin{array}{llllll}\mathrm{Y} & 1 / 4 & 31.2041 & 0.2718 \mathrm{X}, & \mathrm{R}^{2} & 1 / 4\end{array}\right.$ $\left.0.7396^{* *}\right)$. Root dry weight was significantly related to grain yield (Y1/47.6345p5.8030X0.4081X ${ }^{2}, \quad R^{2} \quad 1 / 4$ $0.8747 * *$; Fageria, 2011). Figure 14 shows root growth of upland rice under different $\mathrm{N}$ timing treatments. Root dry we ight was least (treatment $\mathrm{T}_{2}$ ) when all $\mathrm{N}$ fertilizer was applied at planting. Root and shoot yields were better in treatments $\mathrm{T}_{3}$ and $\mathrm{T}_{4}$, when $\mathrm{N}$ was applied later in the growth cycle (Fageria, 
2011). Better root growth may be responsible for higher absorption of nutrients and water in the $T_{3}$ and $T_{4}$ treatments which resulted in higher grain and straw yields. The depth of $\mathrm{N}$ placement can influence $\mathrm{NO}_{3}-\mathrm{N}$ distribution in the soil and root growth of wheat (Sharma and Chaudhary, 1984). Root length density decreased abruptly below the $15 \mathrm{~cm}$ depth when $\mathrm{N}$ was surface applied, whereas root length density decreased more gradually below $15 \mathrm{~cm}$ when $\mathrm{N}$ was placed at the $10 \mathrm{~cm}$ depth. Drew (1975) reported that barley root weight increased in the zone of nutrient localization and decreased in the deficient zone. Murphy and Zaurov (1994) reported that $\mathrm{N}$ fertilization at the 5,10 , and $15 \mathrm{~cm}$ soil depths produced greater root mass than $\mathrm{N}$ fertilization at $0 \mathrm{~cm}$ soil depth or surface fertilization. Wang et al (2008) reported that the maize roots grew optimally in the N100 and N200 N treatments, whereas in the N400 treatment they showed limited root growth. This inhibition was clear to the naked eye.

\section{Phosphorus}

Phosphorus is one of the most yield-limiting nutrients in tropical highly weathered soils (Fageria, 2009). The deficiency of $P$ in these soils may be related to the low natural level of this element in these soils as well as to the immobilization of $\mathrm{P}$ in these soils (Fageria and Baligar, 2008). Phosphate plays many roles in the physiology and biochemistry of pants. It is a component of important compounds like phospholipids, phosphorylated sugars and proteins, DNA (deoxyribonucleic acid), and RNA (ribonucleic acid). It is also a component of ATP (adenosine 5-triphosphate), PEP (phosphoenolpyruvate), NADPH (nicotinamide adenine dinucleotide phosphate, reduced), and other biochemicals that use the phosphate bond in energy utilization and storage (Blevins, 1994).
Phosphorus is a key nutrient essential for root development in highly weathered tropical soils. Overall, the root growth of cereals and legume crops was reduced if $\mathrm{P}$ was deficient. Most studies indicate that, within certain limits, both root and shoot growthvary similarly as P level increases. Above certain levels, further increases in $\mathrm{P}$ supply do not affect root or shoot growth (Troughton, 1962). Fageria et al., (2006) reported that root dry weight was reduced $62 \%$ in rice, $74 \%$ in common bean, $50 \%$ in corn, and $21 \%$ in soybean without added soil $\mathrm{P}$, compared to adequate P. Fageria et al., (2011) studied the influence of phosphorus on root dry weight and root length of 20 upland rice genotypes grown on a Brazilian Oxisol. Phosphorus level and genotype interactions for root dry weight and root length were significant, indicating different responses of genotypes to varying P levels (Table 3).

Root dry weight of 20 upland rice genotypes at low P level varied from 2.00 to $5.68 \mathrm{~g}$ plant ${ }^{-1}$, with an average value of $3.41 \mathrm{~g}$ plant 1 . At the high P level, root dry weight varied from 2.43 to $8.55 \mathrm{~g} \mathrm{plant}^{-1}$, with an average value of $4.01 \mathrm{~g}^{\mathrm{plant}}{ }^{-1}$. However, the effect of $\mathrm{P}$ level on root system dry weight was not significant. Root length varied from 23.00 to $38.33 \mathrm{~cm}$ with an average value of $30.9 \mathrm{~cm}$ at low $\mathrm{P}$ level. At high $\mathrm{P}$ level, root length varied from 23.67 to $34.33 \mathrm{~cm}$, with an average value of $28.20 \mathrm{~cm}$. There was a significant $10 \%$ decrease in root length at the high $\mathrm{P}$ level compared to the low $\mathrm{P}$ level. However, higher $\mathrm{P}$ level roots had more fine hairs compared to lower $\mathrm{P}$ level (personal observations). Figures 16 show root growth of upland rice under different $P$ rates. Unlike the data cited above, root growth of all the cultivars/genotypes increased with increasing $\mathrm{P}$ levels. Maximum root length of tropical legume cover crops varied from 15.5 to $36 \mathrm{~cm}$ at the low P level, from 20.5 to $50.33 \mathrm{~cm}$ at the medium P level and 18.33 to $52.33 \mathrm{~cm}$ at 
the high $\mathrm{P}$ level. Overall, root length also increased with increasing $\mathrm{P}$ level show root growth of tropical legume cover crops as influenced by $\mathrm{P}$ levels. The improvement in root length by improved $\mathrm{P}$ nutrition has been reported by Fageria (2009) in various crop species. Mengel et al., (2001) reported that mineral nutrition has tremendous effects on root growth, development, and function and, subsequently, the ability of roots to absorb and translocate nutrients. These authors further reported that mineral deficiencies induce considerable variations in the growth and morphology of roots and such variations are strongly influenced by plant species and genotypes.

The influence of $\mathrm{P}$ fertilization on dry bean root dry weight was studied by Fageria (1989). Root dry weight of three bean genotypes increased significantly in a quadratic fashion but differed from genotype to genotype (Table 4).

The variability in root dry weight due to $\mathrm{P}$ fertilization was about $52 \%$ in genotype Carioca, $35 \%$ in genotype CNF10, and $70 \%$ in genotype CNF4856. Such information may contribute to the selection of cultivars specific to soil type and management systems, resulting in increasing yields on the soils of variable P fertility (Fageria, 1989).

\section{Potassium}

Potassium plays an important role in the growth and development of plants, including the root system. Many enzymes are activated in plants by potassium, and it is also required for photosynthesis, transport of photosynthate, and protein synthesis (Blevins, 1994). Potassium plays a role in cell growth following cell division by serving as a major component in cell turgor. It also maintains ionic balance and electrical neutrality in plants. Crops that produce large quantities of protein per unit area of land require more $\mathrm{K}$ than those that produce less protein (Blevins, 1994). Potassium also plays an important role in opening and closing the stomata.

Tennant (1976) reported that potassium deficiency stops root growth completely within 10-12 days of planting in wheat. Inadequate $\mathrm{K}$ reduces root growth and consequently, crop yields (Baligar et al., 1998). A defi-ciency of $K$ in an Inceptisol reduced root growth by $23 \%$ in lowland rice, by $30 \%$ in dry bean, by $12 \%$ in corn, and by $11 \%$ in soybean (Baligar et al., 1998). On an Oxisol, a 35\% lower root dry mass was observed in 13 corn genotypes when $\mathrm{K}$ levels were 0 versus $200 \mathrm{mg} \mathrm{kg}^{-1}$ of soil (Baligar et al., 1998). Data in Table 5 show that at $0 \mathrm{mg}$ $\mathrm{K} \mathrm{kg}^{-1}$ of soil root dry weight of common bean (P. vulgaris L.) genotypes varied from 1.54 to $3.14 \mathrm{~g}$ per 3 plants, a variation of twofold. At the $200 \mathrm{mg} \mathrm{K} \mathrm{kg}^{1}$ level, root dry weight varied from 1.50 to $2.30 \mathrm{~g}$ per 3 plants, a variation of 1.5-fold. Similarly, maximum root length varied from 42 to 46 $\mathrm{cm}$ at low $\mathrm{K}$ level and $32-44 \mathrm{~cm}$ at higher $\mathrm{K}$ level. At the higher K level, there was a slight decrease in the root length of all the genotypes, and the root weight of three genotypes also decreased at the higher $\mathrm{K}$ level. However, at the higher $\mathrm{K}$ level, there were more root hairs than at the low $\mathrm{K}$ level (visual observations).

There is widespread evidence for genotype diversity in the root characteristics of many crops in response to the environment and increasing interest in using this diversity to improve agricultural production and consequently, nutrient-use efficiency (Gregory, 1994). Mullins et al., (1994) studied $\mathrm{K}$ placement effects on the root growth of cotton grown on a fine sandy loam soil. Root density measurements taken in-row showed that root growth at depths $>20 \mathrm{~cm}$ was improved with in-row subsoil additions of K. Tupper (1992) also observed increased cotton taproot length when $\mathrm{K}$ fertilizer was 
band-applied in the subsoils of Mississippi soils with low soil-test K. On the other hand, Yibrin et al., (1993) reported that localized applications of $\mathrm{K}$ did not promote root growth. However, $\mathrm{K}$ has been shown to promote the root growth of some vegetable crops (Zhao et al., 1991). Fageria (1992) determined the root growth of rice grown in nutrient solution as well as in an Oxisols at the stress and nonstress levels of $\mathrm{K}$. At the stress levels of $K$, rice root growth was reduced compared with nonstress levels. Alfalfa herbage yield, root weight, and root total nonstructural carbohydrates increased with increasing $\mathrm{K}$ fertilizer (Kitchen et al., 1990).

\section{Calcium}

Absolute Ca deficiency is difficult to identify on plants grown in acidic soils. Most acidic soils contain adequate total $\mathrm{Ca}$ for most plants, and Ca-deficiency symptoms are rarely observed in the field. Only in highly leached, acidic, low-cation exchangesoils (Oxisols and Ultisols) would absolute deficiencies be likely to occur. Levels of $\mathrm{Ca}$ required for essential growth functions are so low as to approach those of micronutrients. Hence, the major role of $\mathrm{Ca}$ in soils and in plants is to exclude or detoxify other elements such as Al, Mn, and heavy metals that might otherwise become toxic.

Gonzalez-Erico et al.,

evaluated the maize response to deep incorporation of limestone on an Oxisol. They reported that incorporation of limestone to depths of $30 \mathrm{~cm}$ improved root growth and increased water utilization and grain yield of maize. Similar results were obtained for maize and cotton when limestone was incorporated to depths up to $45 \mathrm{~cm}$ (Doss et al., 1979). Suitable diagnostic indices for prediction of $\mathrm{Ca}$ limitations on root growth are either Ca saturation of the effective CEC or $\mathrm{Ca}$ activity ratio of the soil solution, which has been defined as the ratio of $\mathrm{Ca}$ activity to the sum of the activities of $\mathrm{Ca}, \mathrm{Mg}, \mathrm{K}$, and $\mathrm{Na}$ (Bruce et al., 1988). Values corresponding to 90\% relative root length (RRL) of soybean were 0.05 for the $\mathrm{Ca}$ activity ratio and $11 \%$ for $\mathrm{Ca}$ saturation. Calcium activity and $\mathrm{Ca}$ concentrations in soil solutions and exchangeable $\mathrm{Ca}$ were less useful for diagnostic indices (Bruce et al., 1988). The root growth of soybean was improved with the addition of $12 \mathrm{Mg}$ lime per hectare compared to control treatment (Fig. 18).

\section{Magnesium}

Magnesium is an essential macronutrient for plant growth. The most well known and important role of $\mathrm{Mg}$ is its occurrence in chlorophyll molecules. In addition to this, $\mathrm{Mg}$ is required for many essential physiological reactions, especially phosphorylation reactions (Mengel and Kirkby,1978). Fageria and Souza (1991) determined the effects of $\mathrm{Mg}$ levels on root weights of rice, common bean, and cowpea grown in an Oxisols of Central Brazil.

Dry weights of rice roots were higher at the lowest $\mathrm{Mg}$ concentration compared with the highest soil $\mathrm{Mg}$ concentration. Initial exchangeable Mg levels of surface soils were $0.1 \mathrm{cmol} \mathrm{kg}^{-1}$. They increased to $0.3 \mathrm{cmol}$ $\mathrm{kg}^{-1}$ within 3 days after liming and to 0.75 cmol $\mathrm{kg}^{-1}$ at harvest time (33 days after sowing). The lack of growth responses to applications of $\mathrm{Mg}$ indicated that this level of exchangeable $\mathrm{Mg}$ was adequate to meet $\mathrm{Mg}$ requirements of upland rice grown in this limed soil. Dry weight of roots of common bean increased with $\mathrm{Mg}$ application up to 3 cmol kg-1 of soil. Similarly, significant responses of cowpea root growth to soil $\mathrm{Mg}$ levels were observed, and maximum root weight was achieved at $2.5 \mathrm{cmol} \mathrm{Mg} \mathrm{kg}^{-1}$ of soil. 


\section{Sulfur}

Sulfur has long been recognized as an essential element for plant growth and development and classified as a macronutrient. Crop responses to applied sulfur have been reported in a wide range of soils in many parts of the world. Sulfur plays many important roles in the growth and development of plants. Fageria and Gheyi (1999) summarized important functions of the sulfur in the plant. It is an important component of two amino acids, cysteine and methionine, which are essential for protein formation. Since animals cannot reduce sulfate, plants play a vital role in supplying essential S-containing amino acids to them. Sulfur plays an important role in enzyme activation. It promotes nodule formation in legumes. Sulfur is necessary in chlorophyll formation, although it is not a constituent of chlorophyll. Maturity of seeds and fruits is delayed in the absence of adequate sulfur. Sulfur is required by the plants in the formations of nitrogenase. It increases the crude protein content of forages and improves the quality of cereals for milling and baking. Sulfur increases the oil content of oilseed crops and increases winter hardiness in plants. It increases drought tolerance in plants, controls certain soil-borne diseases, and helps in the formation of glucosides that give characteristic odors and flavors to onion, garlic, and mustard. Sulfur is necessary for the formation of vitamins and synthesis of some hormones and glutathione, and it is involved in oxidation-reduction reactions. Sulfur improves tolerance to heavy metal toxicity in plants, and it is a component of sulfur contain sulfolipids.

Organic sulfates may serve to enhance the water solubility of organic compounds, which may be important in dealing with salinity stress, and fertilization with sulfate decreases fungal diseases in many crops. Few studies have assessed the impacts of sulfur on root growth and function; however, the effects of sulfur on root growth may be similar to those of N. Zhao et al., (2008) reported that $\mathrm{S}$ application increased the root number and root dry weight of soybean compared to control treatment. Bairwa et al (2012) reported that application of sulphur upto 45 $\mathrm{kg} \mathrm{ha}^{-1}$ significantly increased the grain yield of summer greengram by 14.41 percent over control.

\section{Micronutrients}

Micronutrients have also been called minor or trace elements, indicating that their required concentrations in plant tissues are small compared to the macronutrients (Mortvedt, 2000). Based on physico- chemical properties, except $\mathrm{B}$ and $\mathrm{Cl}$, the essential micronutrients are metals. Even though micronutrients are required in small quantities by field crops, their influence can be as great as that of macronutrients in crop production. Micronutrients are normally constituents of prosthetic groups that catalyze redox processes by electron transfer (such as with the transition elements $\mathrm{Cu}, \mathrm{Fe}, \mathrm{Mn}$, and $\mathrm{Mo}$ ) and form enzyme-substrate complexes by coupling enzymes with substrates (Fe and $\mathrm{Zn}$ ) or enhance enzyme reactions by influencing molecular configurations between enzyme and substrate (Zn) (Fageria et al., 2002).

Micronutrient deficiencies in crop plants are widespread because of (i) increased micronutrient demands from intensive cropping practices and adaptation of highyielding cultivars which may have higher micronutrient demand, (ii) enhanced production of crops on marginal soils that contain low levels of essential micronutrients, (iii) increased use of high-analysis fertilizers with low amounts of micronutrients, (iv) decreased use of animal manures, composts, and crop residues, (v) use of many soils that 
are inherently low in micronutrient reserves, (vi) use of liming in acid soils, and (vi) involvement of natural and anthropogenic factors that limit adequate supplies and create elemental imbalance (Fageria et al., 2002).

\section{Zinc}

Deficiency of $\mathrm{Zn}$ in crop production is spread worldwide. Graham (2008) reported that half of the world's soils are intrinsically deficient in ZnMicronutrient deficiencies are also a worldwide problem in human health (Welch, 2008). Zinc deficiency is the highest priority among micronutrients for agriculture to address (Graham, 2008). In the Brazilian Cerrado region, $\mathrm{Zn}$ deficiency is very common in annual crops, especially upland rice and corn (Fageria, 2009).

Zn-deficiency symptoms in upland rice and corn grown on Brazilian Oxisols. Data in Table 7 show that $\mathrm{Zn}$ application of up to 120 mg kg ${ }^{1}$ improved the root growth of upland rice and wheat significantly. Similarly, Figure 21 show improvement in the root growth of soybean and dry dean, respectively, with the addition of $\mathrm{Zn}$.

\section{Boron}

Boron deficiency is common for plants grown in arid, semiarid, and heavy rainfall areas in calcareous, sandy, light textured, acid, and low-OM soils. Differences between B sufficiency and toxicity are narrow, and soils supplied with high amounts of municipal compost, sludge, and biosolids tend to accumulate high amounts of $\mathrm{B}$, which may result in B toxicity. Boron is essential for pollen germination and pollen tube growth in crop plants. Boron requirements of dicots are generally higher than monocots. Fageria (2000) reported that maximum root growth of upland rice can be achieved with the

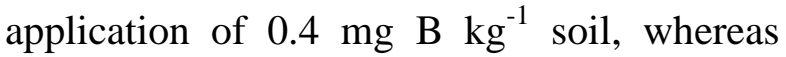
maximum root growth of dry bean required $1.9 \mathrm{mg} \mathrm{B} \mathrm{kg}^{1}$ of soil. Figure 22 shows that B requirements for root growth varied among the crop species. Application of $24 \mathrm{mg} \mathrm{B} \mathrm{kg}^{-1}$ soil decreased the root dry weight of upland rice and corn in greenhouse studies. However, application of B at lower rates to the same soil increased the root dry weight in dry bean, soybean, and wheat (Fig. 22).

\section{Copper}

Copper deficiency is often observed on plants grown in soils inherently low in $\mathrm{Cu}$ (coarsetextured and calcareous soils) and in soils high in $\mathrm{OM}$, where $\mathrm{Cu}$ complexes with organic substances (Fageria et al., 2002). Higher-than- normal $\mathrm{Cu}$ supplies usually inhibit root growth more than shoot growth. Use of $\mathrm{Cu}$-containing fungicides and anthelmintic compounds in agriculture has resulted in $\mathrm{Cu}$ toxicity in some plants, but naturally occurring $\mathrm{Cu}$ toxicity is relatively uncommon. Root dry weight of wheat and root length of dry bean were significantly increased by the application of copper fertilization (Table 8).

\section{Iron}

Iron deficiency is a worldwide problem and occurs in numerous crops. Iron deficiency occurs not because of Fe scarcity in soil or plants, but because various soil and plant factors affect $\mathrm{Fe}$ availability, inhibit its absorption, or impair its metabolic use. Plant species that commonly become Fe-deficient are peanut (A. hypogaea L.), soybean (G. max L.), sorghum (Sorghum bicolor L. Moench), and upland rice (O. sativa L.). Iron deficiency reduces root growth (Table 9).

Iron toxicity (indicated by leaf bronzing) can be serious for production of crops in waterlogged soils. For wetland rice, $\mathrm{Fe}$ toxicity is the second most severe yield- 
limiting nutrient disorder, and it has been reported in South America, Asia, and Africa. Iron toxicity decreases the root growth of lowland rice (Fageria et al., 2008); however, genotypic differences exist (Fig. 23).

\section{Other micronutrients}

In addition to zinc, boron, copper, and iron, the other micronutrients that are essential for the growth of higher plants are manganese, molybdenum, chlorine, and nickel. Manganese deficiency has been reported for plants grown in the coarse-textured and poorly drained coastal plain soils of the United States and in the soils of Central America, Bolivia, and Brazil. In Europe, Mn deficiency has been reported on plants grown in peaty (England and Denmark), coarsetextured (Sweden and Denmark), coarse/fine textured (Netherlands), podzolic, and brown forest (Scotland) soils. Manganese deficiency has also been reported on plants grown in the semiarid regions of China, India, southeast and western Australia, Congo, Ivory Coast, Nigeria, and other western African countries. Manganese toxicity on crop plants grown in many parts of the world has been reported to be more important than $\mathrm{Mn}$ deficiency. Molybdenum is the least abundant of the micronutrients in the lithosphere.

In Australia, Mo deficiency occurs on crops grown in soils derived from sedimentary rocks, basalts, and granites. Peaty, alkaline, and poorly drained soils commonly have high Mo. Iron oxides adsorb more Mo than $\mathrm{Al}$ oxides and clay mineralogy can affect Mo adsorption, in the order montmorillonite > illite > kaolinite. Hydrous ferric oxides or ferric oxide molybdate complexes and insoluble ferric molybdates may form in well-aerated soils so that Mo solubility and availability to plants is low. In poorly drained soils, the formation of soluble ferrous molybdates or molybdites may lead to high Mo availability to plants. Plants grown in high Mo soils of the intermountain valleys of western United States have been reported to accumulate high Mo which has induced "molybdenosis" (Cu deficiency) in cattle.

Chloride is essential to higher plants and is required for the water-splitting reactions in photosystem II. Nickel has been shown to be essential for soybean, and it is known to be a constituent of urease. Since urea is a widely used fertilizer in crop plants worldwide, Ni nutrition could be important. Information on the influence of these micronutrients on the root growth of crop plants is not available, and this aspect is not discussed here.

\section{Management Strategies for Maximizing Root Systems}

Root growth of crop plants can be improved by adopting management practices that modify soils to fit crops, as well as to modify the plants to fit the soil. Both of these strategies can be combined to get maximum economic results.

\section{Soil management}

Soil management practices that can improve root growth of crop plants include liming acid soils, use of gypsum, maintenance of organic matter, use of adequate rates, sources and methods of fertilizer application, and deep plowing.

\section{Liming acid soils}

Liming is the most common and effective practice to reduce soil acidity. Lime requirements of crops grown on acid soils are determined by the quality of liming material, status of soil fertility, crop species and cultivar within species, crop management practices, and economic considerations. Soil $\mathrm{pH}$, base saturation, and aluminum saturation are important acidity indices that are used to 
determine liming. Liming improves soil $\mathrm{pH}$, $\mathrm{Ca}$, and $\mathrm{Mg}$ contents and reduces $\mathrm{Al}$ concentrations in the soil solution. In addition, liming improves beneficial microbe populations in the soil. Furthermore, liming improves $\mathrm{P}$ concentration in the soil solution by reducing $\mathrm{P}$ immobilization by $\mathrm{Fe}$ and $\mathrm{Al}$ in acid soils. All these beneficial effects of liming improve the root growth of crop plants. Nurlaeny et al., (1996) found that liming increased shoot dry weight, total root length, and mycorrhizal colonization of roots in soybean and corn grown on tropical acid soils. Gonzalez (1976) reported that incorporation of lime to a $30 \mathrm{~cm}$ soil depth allowed the corn roots to penetrate and use stored water throughout the lime layer. Data in Table 10 show that liming increases soil $\mathrm{pH}$ and consequently, the root dry weight of dry bean grown on a Brazilian Oxisol.

\section{Use of gypsum}

Gypsum $\left(\mathrm{CaSO}_{4} \quad 2 \mathrm{H}_{2} \mathrm{O}\right)$ or phosphogypsum (e.g., byproducts of phosphoric acid manufacturing processes) applications are used to leach $\mathrm{Ca}$ deeper into soil profiles where $\mathrm{Ca}$ can replace $\mathrm{Al}$ on cation exchange complexes. Much of the $\mathrm{Al}$ displaced by $\mathrm{Ca}$ can be leached from the root zones. This practice works well in sandy soils or Oxisols with clay loam aggregates which behave hydrologically like sands. Poor root growth of crop plants has been frequently observed in highly weathered acid soils in various countries. The chemical factor identified as most responsible for poor root growth is excess soluble $\mathrm{Al}$. Excess $\mathrm{Al}^{3 \mathrm{~b}}$ has been reported to inhibit root growth by binding to the $\mathrm{PO}_{4}$ portion of DNA in the root cell nuclei, reducing template activity and thus cell division. Inlegumes, it has been shown to impair the growth of root hairs and rhizobia, reducing root nodule initiation and function (Munns and Franco, 1982). Excess Al may also adversely affect the root and overall plant growth in nonphytotoxic ways by competing
withCa and $\mathrm{Mg}$ for uptake by plants (Rengel and Robinson, 1989). The use of gypsum can neutralize subsoil acidity by leaching $\mathrm{CaSO}_{4}$ and forming $\mathrm{AlSO}_{4 \mathrm{p}}$ which is not toxic for root growth (Alva and Sumner, 1989). Ritchey et al., (1980) reported that application of gypsum increased subsoil $\mathrm{Ca}$ and $\mathrm{Mg}$ while decreasing $\mathrm{Al}$ and improving the root growth of corn in Brazilian Oxisol.

\section{Maintenance of adequate amounts of organic matter}

The benefits of organic matter addition to soils include improving nutrient cycling and availability to plants through direct additions as well as through modification in soil physical and biological properties. The complementary use of organic manures and chemical fertilizers has proved to be the best soil fertility management strategy in the tropics. Enhanced soil organic matter increases soil aggregation and water-holding capacity, provides an additional source of nutrients, and reduces $\mathrm{P}$ fixation, toxicities of $\mathrm{Al}$ and Mn, and leaching of nutrients. Buildup of organic matter through additions of crop and animal residues increases the population and species diversity of microorganisms and their associated enzyme activities and respiration rates. The use of organic compost may result in a soil that has greater capacity to resist the spread of plant pathogenic organisms. The improvement in the overall soil quality may produce more vigorous root systems and higher crop yields.

Use of adequate nutrient rates, sources, and methods of application

Use of adequate rates and effective sources of nutrients are important management practices to improve crop yield and plant root systems. In addition, appropriate methods of fertilizer application are also important for the development of 
vigorous root systems. Immobile nutrients like $\mathrm{P}$ and $\mathrm{K}$ should be applied in bands to improve their uptake by plant roots.

\section{Deep plowing}

Deep plowing improves soil conditions for root growth by breaking compacted layers that roots cannot readily penetrate. If water tables are near the soil surfaces, drainage can also be useful. When depths to root-restricting hardpans are relatively shallow $(<0.25 \mathrm{~m})$, chisel plowing can be effective for disrupting compacted layers.

\section{Mulching, greater sowing depth, and sowing larger seeds}

Root growth may be manipulated through cultural practices like mulching, which can affect soil temperatures. Warmer soil temperatures generally produce larger root systems. In addition, crop residues on soil surfaces decrease soil evaporation and improve water-use efficiency. Greater sowing depths may decrease seedling emergence rate, but it can also increase the survival of emergent seedlings by increasing water availability. Larger seeds generally produce seedlings with more extensive root systems. Sowing good quality seeds could also improve root systems.

\section{Integrated cropping systems and pest management}

Reduced tillage, N side-dressing, and early planting can be included in integrated pest management programs with no risk of increasing potential for root damage from western maize rootworm. Miltner et al., (1991) reported that cyst nematodes suppressed soybean root growth on susceptible cultivars, whereas root growth of tolerant cultivars was stimulated by the presence of soybean cyst nematodes. The use of tolerant or nutrient-use-efficient cultivars may be an important practice to improve root growth in stress environments. Stress-tolerant genotypes are being identified and bred worldwide to solve some of the most difficult problems of soil fertility such as subsoil acidity, salinity, low plant availability of Fe in calcareous soils, and low $\mathrm{P}$ availability in acidic soils. Rhizobial species/strains differ markedly in tolerance to low $\mathrm{pH}$, and toxicities of $\mathrm{Al}$ and $\mathrm{Mn}$ in tropical soils have been identified. The use of improved strains can improve $\mathrm{N}_{2}$ fixation and the root growth of legumes grown in acidic soils.

\section{Plant management}

Plant management is another important strategy in improving root systems of crop plants. Adequate plant density and spacing can improve the root growth of crop plants.

\section{Genetic variability}

An important plant management strategy is to exploit root system genetic variability of crop species or cultivars within species. Plant genetic variability can be defined as the heritable characters of a particular crop species or cultivar that produce differences in the growth or production among species, or cultivars of the same species, under favorable or unfavorable growth conditions. Cultivar differences in root size are quite common and have been related to differences in nutrient uptake. Differences between white clover (T. repens L) populations and cultivars in $\mathrm{P}$ uptake per plant at low levels of $\mathrm{P}$ have been related to differences in root size and absolute growth rate. There is widespread evidence for genotype diversity in the root characteristics of many crops in response to environment and increasing interest in using this diversity to improve agricultural production and consequently, nutrient use efficiency. 
Mineral deficiency and toxicity, mechanical impedance, moisture stress, oxygen stress, and temperature have tremendous effects on root growth, development, and function and, subsequently, the ability of roots to absorb and translocate nutrients. Mineral deficiency induces considerable variations in growth and morphology of roots, and such variations are strongly influenced by plant species and genotypes. Overall, the growth of the main axis is little affected by nutrient deficiency, but growth of lateral branches and their elongation rates appear to be substantially reduced.
Baligar et al., (1998) summarized the effects of various essential elements as follows: nitrogen deficiency increases root hair length, increases or has no effect on root hair density, and reduces branching. Phosphorus deficiency increases the overall growth of roots and root hair length, increases the number of secondorder laterals, and either increases or does not affect root hair density. $\mathrm{K}$ and $\mathrm{Ca}$ deficiencies reduce root growth; however, high $\mathrm{Mg}$ levels reduce the dry mass of roots. The effects of these nutrient stress factors on nutrient-use efficiency have not been well explored.

Table.1 Root length and dry weight of upland rice as influenced by $\mathrm{N}$ timing treatments

\begin{tabular}{|l|c|c|}
\hline \multicolumn{1}{|c|}{ Nitrogen timing treatment } & Root length $(\mathbf{c m})$ & Root dry weight (g/plant $)$ \\
\hline T1- $1 / 2$ at sowing $+1 / 2$ at PI & 28.75 & 4.21 \\
\hline T2- total N at sowing & 35.00 & 2.56 \\
\hline T3- $1 / 3$ at sowing $+1 / 3$ at AT $+1 / 3$ at PI & 25.75 & 5.74 \\
\hline T4- $1 / 2$ at initiation of Tillering+ $1 / 2$ at PI & 27.00 & 7.70 \\
\hline T5-2/3 at sowing + 1/3 at PI & 28.25 & 4.98 \\
\hline
\end{tabular}

Table.2 Influence of P fertilization on root growth of three dry bean genotype at harvest

\begin{tabular}{|c|l|l|l|}
\hline \multicolumn{4}{|c|}{ Root dry weight (g per 2 plants) } \\
\hline P rate $\left(\mathrm{mg} \mathrm{kg}^{-1}\right)$ & Carioca & CNF 10 & CNF4856 \\
\hline 0 & 0.29 & 0.45 & 0.23 \\
\hline 25 & 1.13 & 1.79 & 1.38 \\
\hline 50 & 1.66 & 1.28 & 1.83 \\
\hline 75 & 1.31 & 1.29 & 1.52 \\
\hline 100 & 1.34 & 1.60 & 1.59 \\
\hline 125 & 1.62 & 1.33 & 1.78 \\
\hline 150 & 1.31 & 1.75 & 1.82 \\
\hline 175 & 1.18 & 1.29 & 1.48 \\
\hline 200 & 1.79 & 1.50 & 1.67 \\
\hline
\end{tabular}


Table.3 Root dry weight and root length of six common bean genotype influenced by K levels

\begin{tabular}{|l|l|l|l|l|}
\hline \multirow{2}{*}{ Genotype } & \multicolumn{2}{|l|}{$0 \mathrm{mg} \mathrm{K} \mathrm{kg}^{-1}$} & \multicolumn{2}{l|}{$200 \mathrm{mg} \mathrm{K} \mathrm{kg}^{-1}$} \\
\cline { 2 - 5 } & Root dry wt & Root length & Root dry wt & Root length \\
\hline Apore & 1.54 & 45 & 1.67 & 32 \\
\hline Perola & 1.97 & 42 & 2.04 & 39 \\
\hline Ruda & 1.94 & 44 & 2.30 & 35 \\
\hline IAC Carrioca & 3.14 & 45 & 1.70 & 38 \\
\hline IAC Precoce & 2.24 & 46 & 1.67 & 36 \\
\hline Safira & 1.77 & 44 & 1.50 & 44 \\
\hline
\end{tabular}

Table.6 Effect of sulphur on yield of summer greengram

Fageria et al., (2008)

\begin{tabular}{|l|l|}
\hline Sulphur & Yield \\
\hline 0 & 617 \\
\hline 15 & 644 \\
\hline 30 & 666 \\
\hline 45 & 692 \\
\hline
\end{tabular}

Table.8 Root dry weight of wheat and root length of dry bean as influenced by copper fertilization

\begin{tabular}{|c|c|c|}
\hline \begin{tabular}{c} 
Cu rate $\left(\mathrm{mg} \mathrm{kg}^{-1}\right)$ \\
\hline 0
\end{tabular} & $\begin{array}{c}\text { Wheat root dry weight } \\
(\mathrm{g})\end{array}$ & $\begin{array}{c}\text { Dry bean root length } \\
(\mathrm{cm})\end{array}$ \\
\hline 2 & 0.53 & 25 \\
\hline 4 & 0.60 & 30 \\
\hline 8 & 0.50 & 27 \\
\hline 16 & 0.48 & 28 \\
\hline 32 & 0.47 & 28 \\
\hline 64 & 0.47 & 24 \\
\hline 96 & 0.43 & 30 \\
\hline
\end{tabular}


Table.9 Root dry weight of lowland rice as influenced by ironconcentration in nutrient solution

\begin{tabular}{|c|c|c|}
\hline \multicolumn{3}{|c|}{ Root dry weight $\left(\mathrm{g} \mathrm{plant}^{-1}\right)$} \\
\hline Fe conc. $\left(\mathrm{mg} \mathrm{L}^{-1}\right)$ & 20 DAT & 60 DAT \\
\hline 0.0 & 0.03 & 0.64 \\
\hline 2.5 & 0.09 & 1.19 \\
\hline 5.0 & 0.13 & 1.05 \\
\hline 10.0 & 0.10 & 1.07 \\
\hline 20.0 & 0.08 & 1.18 \\
\hline 40.0 & 0.11 & 1.24 \\
\hline 80.0 & 0.07 & 0.84 \\
\hline 160.0 & 0.02 & 0.12 \\
\hline
\end{tabular}

Fageria et al., 1981

Baligar et al., (1998) states that low $\mathrm{pH}$ reduces root mass, length, and root hair formation. In alkaline soils, ammonium toxicity causes severe root inhibition and in general, salinity leads to reduction in the mass and length of roots and dieback of laterals.

In conclusion, the study of plant roots is one of the most promising, but least explored, areas of research related to mineral nutrition. Roots are poorly studied primarily because of their physical location and growth habit. Understanding plant root growth is important for improving productivity of annual crops in agroecosystems. Root systems are important plant organs because they absorb water and nutrients and also provide mechanical support to the plant. In addition, roots synthesize growth substances and hormones such as cytokinins that are important in leaf function and possibly, grain development. In plant growth analysis, the role of roots is generally ignored due to the difficulty in getting accurate root growth data under field condition. The principal structure of the root system includes four developmentally distinct classes of roots. These are taproots, basal roots, lateral roots, and shootborn roots.
Current evidence suggests that the four root classes that make up the primary and secondary root systems are physiologically distinct from each other. Rooting depth and spreading capacity are important traits for uptake of water and nutrients. Root growth varies among plant species and cultivars within species and can be modified by environmental factors. Genotypic differences in root growth among crop species and genotypes of the same species under similar and variable environmental conditions are now well demonstrated, and the possibility of developing genotypes of desirable root systems to soil proper-ties offers exciting prospects for the future. Root number, maximum length, and root dry weight increase with increasing levels of macro and micronutrients in the soil to a point beyond which root growth is suppressed. Plant roots together with their associated bacteria and fungi play an important role in the formation, maintenance, and turnover of soil aggregates. Currently, the techniques available to measure root systems are laborious and time consuming, and this limits their use in plant physiological research. Hence, it is necessary to develop root measurement techniques that 
are simple, cheap, and less time consuming.

\section{References}

Allmaras, R. R., Linden, D. R., and Clapp, C. E. 2004. Corn-residue transformations into root and shoot carbon as related to nitrogen, tillage, and stover management. Soil Sci. Soc. Am. J. 68, 1366-1375.

Alva, A. K., and Sumner, M. E. 1989. Alleviation of aluminum toxicity to soybeans by phosphogypsum or calcium sulfate in dilute nutrient solutions. Soil Sci. 147, 278-285.

Anderson, D. S., Teyker, R. H., and Rayburn, A. L. 1991. Nitrogen form effects on early corn root morphological and anatomical development. J. Plant Nutr. 14, 1255-1266.

Atkinson, D. 1990. Influence of root system morphology and development on the need for fertilizers and the efficiency of use. In "Crops as Enhancers of Nutrient Use" (V. C. Baligar and R. R. Duncan, Eds.), pp. 411-450. Academic Press, San Diego, CA.

Aung, L. H. 1974. Root-shoot relation-ships. In "The Plant Root and Its Environment" (E. W. Carson, Ed.), pp. 29-61. University Press of Virginia, Charlottesville, VA.

Bairwa, R.K., Nepalia, N, Balai, C.M,Upadhyay. 2012. Effect of phosphorus and sulphur on yield and economics of summer greengram. Madras Agric. J. 99(7-9): 523-525.

Baligar, V. C. 1986. Interrelationships between growth and nutrient uptake in alfalfa and corn. J. Plant Nutr. 9, 1391-1404.

Baligar, V. C., Fageria, N. K., and Elrashidi, M. 1998. Toxicity and nutrient constraints on root growth. HortScience 33, 960-965.

Barber, S. A., and Silberbush, M. 1984. Plant root morphology and nutrient uptake. In "Roots, Nutrient and Water Influx, and Plant Growth" (S. A. Barber and D. R. Bouldin, Eds.), pp. 65-85. ASA Special Publication No. 49, ASA, CSSA, and SSSA, Madison, WI. 6587.

Beyrouty, C. A., Wells, B. R., Norman, R. J., Marvel, J. N., and Pillow, J. A. 1987. Characterization of rice roots using a minirhizotron technique. In "Minirhizotron Observation Tubes: Methods and Applications for Measuring Rhizosphere Dynamics" (H. M. Taylor, Ed.),, ASA Special Publication No. 50, pp. 99-108. American Society of Agronomy, Madison, WI.
Beyrouty, C. A., Wells, B. R., Norman, R. J., Marvel, J. N., and Pillow, J. A. 1988. Root growth dynamics of a rice cultivar grown at two locations. Agron. J. 80, 1001-1004.

Blevins, D. G. 1994. Uptake, translocation, and function of essential mineral elements in crop plants. In "Physiology and Determination of Crop Yield" (G. A. Peterson, Ed.), pp. 259-275. ASA, CSSA, and SSSA, Madison, WI.

Borg, H., and Grimes, D. W. 1986. Depth development of roots with time: An empirical description. Trans. Am. Soc. Agric. Eng. 29, 194-197.

Brouwer, R. (1966). Root growth of grasses and cereals. In "The Growth of Cereals and Grasses" (F. L. Milthorpe and D. J. Irvins, Eds.), pp. 153-166. Butterworth, London.

Brown, S. C., Keating, J. D. H., Gregory, P. J., and Cooper, P. J. M. 1987. Effects of fertilizer, variety and location on barley production under rainfed conditions in northern Syria. I. Root and shoot growth. Field Crops Res., 16, 53-66.

Bruce, R. C., Warrell, L. A., Edwards, D. G., and Bell, L. C. 1988. Effects of aluminum and calcium in the soil solution of acid soils on root elongation of Glycine max cv. Forrest. Aust. J. Agric. Res., 39, 319-338.

Cakmak, I., Hengeler, C., and Marschner, H. 1994. Changes in phloem export of sucrose in leaves in response to phosphorus, potassium and magnesium deficiency in bean plants. J. Exp. Bot. 45, 1251-1257.

Champigny, M. L., and Talouizte, A. 1981. Photosynthate distribution and metabolic fate in relation to nitrogen metabolism in wheat seedlings. In "Photosynthesis: IV. Regulation of Carbon Metabolism" (G. Akoyunoglou, Ed.), pp. 645-652. Balban International Science Services, Philadelphia, PA.

Comfort, S. D., Malzer, G. L., and Busch, R. H. 1988. Nitrogen fertilization of spring wheat genotypes: Influence on root growth and soil water depletion. Agron. J. 80, 114-120.

Costa, C., Dwyer, L. M., Zhou, X., Dutilleul, P., Hamel, C., Reid, L. M., and Smith, D. L. 2002. Root morphology of contrasting maize genotypes. Agron. J. 94, 96-101.

Davidson, R. L. 1969. Effect of root/leaf temperature differentials on root/shoot ratios in pasture grasses and clover. Ann. Bot. 33, 561569.

Dingkuhn, M., and Kropff, M. 1996. Rice. In "Photoassimilate Distribution in Plants and 
Crops" (E. Zamski and A. A. Schaffer, Eds.), pp. 519-547. Marcel Dekker, New York.

Doss, B. D., Dumas, W. T., and Lund, Z. F. 1979. Depth of lime incorporation for correction of subsoil acidity. Agron. J. 71, 541-544.

Drew, M. C. 1975. Comparison of the effects of localized supply of phosphate, nitrate, ammonium, and potassium on the growth of the seminal root system and shoot of barley. New Phytol. 75, 470-490.

Durieux, R. P., Kamprath, E. J., Jackson, W. A., and Moll, R. H. 1994. Root distribution of corn: The effect of nitrogen fertilization. Agron. J. 86, 958-962.

Durieux, R. P., Kamprath, E. J., Jackson, W. A., and Moll, R. H. 1994. Root distribution of corn: The effect of nitrogen fertilization. Agron. J. 86, 958-962.

Eghball, B., and Maranville, J. W. 1993. Root development and nitrogen influx of corn genotypes grown under combined drought and nitrogen stresses. Agron. J. 85, 147-152.

Eghball, B., Settimi, J. R., Maranville, J. W., and Parkhurst, A. M. 1993. Fractal analysis for morphological description of corn roots under nitrogen stress. Agron. J. 85, 287-289.

Fageria, N. K. 1989. Effect of phosphorus on growth, yield and nutrient accumulation in the common bean. Trop. Agric. 66, 249-255.

Fageria, N. K. 1992. Maximizing Crop Yields. Marcel Dekker, New York.

Fageria, N. K. 2000. Adequate and toxic levels of boron for rice, common bean, corn, soybean and wheat production in cerrado soil. Braz. J. Agric. Eng. Environ. 4, 57-62.

Fageria, N. K. 2007. Yield physiology of rice. J. Plant Nutr. 30, 843-879.

Fageria, N. K. 2009. The Use of Nutrients in Crop Plants. CRC Press, Boca Raton, FL.

Fageria, N. K. 2011. Root growth of upland rice genotypes as influenced by nitrogen fertilization. J. Plant Nutr. 34, (in press).

Fageria, N. K., and Gheyi, H. R. 1999. Efficient Crop Production Federal University of Paraiba, Campina Grande, Brazil.

Fageria, N. K., and Santos, A. B. 2011. Lowland rice growth and development and nutrient uptake during growth cycle. J. Plant Nutr. 34.

Fageria, N. K., and Souza, C. M. R. 1991. Upland rice, common bean, and cowpea response to magnesium application on an oxisols. Commun. Soil Sci. Plant Anal. 22, 1805-1816.

Fageria, N. K., Baligar, V. C., and Clark, R. B.
2002. Micronutrients in crop production. Adv. Agron. 77, 185-268.

Fageria, N. K., Baligar, V. C., and Clark, R. B. 2006. Physiology of Crop Production. The Howarth Press, New York.

Fageria, N. K., Baligar, V. C., and Li, Y. C. 2008. The role of nutrient efficient plants in improving crop yields in the twenty first century. J. Plant Nutr. 31, 1121-1157.

Fageria, N. K., Moraes, O.P. and Vasconcelos, M.J. 2011. Yield and yield components of upland rice as influenced by nitrogen sources. J. Plant Nutr., 34: 361-370.

Fredeen, A. L., Rao, I. M., and Terry, N. (1989). Influence of phosphorus nutrition on growth and carbon partitioning in Glycine max. Plant Physiol. 89, 225-230.

Gabelman, W. H., Gerloff, G. C., Schettini, T., and Coltman, R. 1986. Genetic variability in root systems associated with nutrient acquisition and use. HortScience 21, 971-973.

Garton, R. W., and Widders, I. E. 1990. N and P preconditioning of small plug seedlings influences growth and yield of processing tomatoes. HortScience 25, 655-657.

Gonzalez, E. E. 1976. Effect of depth of lime incorporation on the growth of corn in Oxisols of central Brazil. Ph.D. Thesis, North Carolina State University, Raleigh, NC, University of Microfilms. Ann Arbor, MI (Diss. Abstract 37:5474).

Gonzalez-Erico, E., Kamprath, E. J., Nederman, G. C., and Soares, W. V. 1979. Effect of depth of lime incorporation on the growth of corn on an Oxisols of central Brazil. Soil Sci. Soc. Am. J. 43, 1155-1158.

Graham, R. D. 2008. Micronutrient deficiencies in crops and their global significance. In "Micronutrient Deficiencies in Global Crop Production" (B. J. Alloway, Ed.), pp. 41-61. Springer, New York.

Gregory, P. J. 1994. Root growth and activity. In "Physiology and Determination of Crop Yield" (G. A. Peterson, Ed.), pp. 65-93. ASA, CSSA, and SSSA, Madison, WI. Martino, D. L., and Shaykewich, C. F. (1994). Root penetration profiles of wheat and barley as affected by soil penetration resistance in field conditions. Can. J. Soil Sci. 74, 193-200.

Gregory, P. J., and Brown, S. C. 1989. Root growth, water use and yield of crops in dry environments: What characteristics are desirable? Asp. Appl. Biol. 22, 235-243. 
Fageria, N. K. (1991). Response of rice cultivars to phosphorus fertilization on a dark red latosol of central Brazil. Rev. Bras. Cienc. Solo 15, 63-67.

Haberle, J., Svoboda, P., and Blaha, L. 1995. The comparison of shoot and root production in old and new cultivars of winter cereals. Rostlinna Vyroba 41, 511-516.

Haberle, J., Svoboda, P., and Ruzek, P. 1996. Root length of winter wheat and the content of mineral nitrogen in soil profile.

Hamblin, A. P., and Tennant, A. P. 1987. Root length density and water uptake in cereals and grain legumes; How well are they correlated? Aust. J. Agric. Res. 38, 513-527.

Hansson, A. C., and Andren, O. 1987. Root dynamics in barley, Lucerne, and meadow fescue investigated with a minirhizotron technique. Plant Soil 103, 33-38.

Harper, J. E. 1994. Nitrogen metabolism. In "Physiology and Determination of Crop Yield" (G. A. Peterson, Ed.), pp. 285-302. ASA, CSSA, and SSSA, Madison, WI. Fageria, N. K., and Baligar, V. C. (2005). Enhancing nitrogen use efficiency in crop plants. Adv. Agron. 88, 97-185.

Helal, H. M., and Sauerbeck, D. 1987. Direct and indirect influences of plant root on organic matter and phosphorus turnover in soil. In "Soil Organic Matter Dynamics and Soil Productivity" (J. H. Couley, Ed.), INTECOl Bulletin 15, pp. 49-58. International Association for Ecology, Athens, GA.

Hoad, S. P., Russell, G., Lucas, M. E., and Bingham, I. J. 2001. The management of wheat, barley, and oat root systems. Adv. Agron. 74, 193-246.

Hsiao, T., Steduto, L. H. P., Rojas-Lara, B., Raes, D., and Fereres, E. 2009. AquaCrop-The FAO crop model to stimulate yield response to water: III. Parameterization and testing for maize. Agron. J. 101, 448-459.

Kaspar, T. C., Taylor, H. M., and Shibles, R. M. 1984. Taproot elongation rates of soybean cultivars in the glasshouse and their relation to field rooting depth. Crop Sci. 24,916-920.

Ketring, D. L., and Reid, J. L. 1993. Growth and peanut roots under field conditions. Agron. J. $85,80-85$.

Kitchen, N. R., Buchholz, D. D., and Nelson, C. J. 1990. Potassium fertilizer and potato leafhopper effects on alfalfa growth. Agron. J. 82, 1069-1074.

Kleeper, B., Belford, R. K., and Rickman, R. W.
1984. Root and shoot development in winter wheat. Agron. J. 76, 117-122.

Kujira, Y., Grove, J. H., and Ronzelli, P. 1994. Varietal differences of root systems in winterwheat seedlings. Jpn. J. Crop Sci. 63, 524-530.

Kuo, S., Sainju, U. M., and Jellum, E. J. 1997. Winter cover crop effects on soil organic carbon and carbohydrate. Soil Sci. Soc. Am. J. $61,145-152$.

Leon, J., and Schwang, K. U. 1992. Description and application of a screening method to determine root morphology traits of cereal cultivars. Z. Acker Pflanzenbau 169, 128-134.

Ludlow, M. M., and Muchow, R. C. 1990. A critical evaluation of traits for improving crop yields in water-limited environments. Adv. Agron 43, 107-153.

Mackay, A. D., and Barber, S. A. 1985. Effect of nitrogen on root growth of two corn genotypes in the field. Agron. J. 78, 659-703.

Maizlish, N. A., Fritton, D. D., and Kendall, W. A. 1980. Root morphology and early development of maize at varying levels of nitrogen. Agron. J. 72, 25-30.

Marschner, H. 1995. Mineral Nutrition of Higher Plants.2nd edn. Academic Press, New York.

Mengel, K., Kirkbay, E. A., Kosegarten, H., and Appel, T. 2001. Principles of Plant Nutrition.5th edn.. Kluwer Academic Publishers, Dordrecht, The Netherlands.

Miltner, E. D., Karnok, K. J., and Hussey, R. S. 1991. Root response of tolerant and intolerant soybean cyst nematodes. Agron. J. 83, 571-576.

Mortvedt, J. J. 2000. Bioavailability of micronutrients. In "Hand Book of Soil Science" (M. E. Sumner, Ed.), pp. D71-D88. CRC Press, Boca Raton, FL.

Mullins, G. L., Reeves, D. W., Burmester, C. H., and Bryant, H. H. 1994. In-row subsoiling and potassium placement on root growth and potassium content of cotton. Agron. J. 86, 136139.

Munns, D. N., and Franco, A. A. 1982. Soil constraints to legume production. In "Biological Nitrogen Fixation for Tropical Agriculture" (P. H. Graham and S. C. Harris, Eds.), pp. 135-152. Centro Internacional de Agricultura Tropical, Cali, Colombia.

Murphy, J. A., and Zaurov, E. 1994. Shoot and root growth response of perennial ryegrass to fertilizer placement depth. Agron. J. 86, 828832.

Nurlaeny, N., Marschner, H., and George, E. 1996. 
Effects of liming and mycorrhizal colonization on soil phosphate depletion and phosphate uptake by maize (Zea mays L.) and soybean (Glycine max L.) grown in two tropical acid soils. Plant Soil 181, 275-285.

O’Toole, J. C., and Bland, W. L. 1987. Genotypic variation in crop plant root systems. Adv. Agron. 41, 91-145.

Oritani, T. 1995. Cytokinins. In "Science of the Rice Plant" (T. Matsuo, K. Kumazawa, R. Ishii, K. Ishihara, and H. Hirata, Eds.), Vol. 2, pp. 189198. Food and Agriculture Policy Research Center, Tokyo.

Pinton, R., and Varannini, Z. 2001. The rhizosphere as a site of biochemical interactions among soil components, plants and microorganisms. In "The Rhizosphere: Biochemical and Organic Substances at the Soil-Plant Interface" (R. Pinto, Z. Varanini, and P. Nannipieri, Eds.), pp. 1-17. Marcel Dekker, New York.

Qin, R., Stamp, P., and Richner, W. 2005. Impact of tillage and banded starter fertilizer on maize root growth in the top 25 centimeters of the soil. Agron. J. 97, 674-683.

Rengel, Z., and Robinson, D. L. 1989. Aluminum effects on growth and micronutrient uptake by annual ryegrass. Agron. J. 81, 208-215.

Ritchey, K. D., Souza, D. M. G., Lobato, E., and Correa, O. 1980. Calcium leaching to increase rooting depth in Brazilian savannah Oxisol. Agron. J. 72, 40-44.

Rostlinna Vyroba 42, 193-197.Steponkus, P. J., Cutler, J. M., and O'Toole, J. C. 1980. Adaptation to water stress in rice. In "Adaptation of Plants to Water and High Temperature Stress" (N. C. Turner and P. J. Kramer, Eds.), pp. 401-418. John Wiley \& Sons, New York.

Russell, R. S. 1977. Plant Root Systems. McGrawHill, New York.

Sainju, U. M., Singh, B. P., and Whitehead, W. F. 2005. Tillage, cover crops, and nitrogen fertilization effects on cotton and sorghum root biomass, carbon, and nitrogen. Agron. J. 97, 1279-1290.

Sanchez, J. E., Paul, E. A., Wilson, T. C., Smeenk, J., and Harwood, R. R. 2002. Corn root effects on the nitrogen supplying capacity of a conditioned soil. Agron. J. 94, 391-396. Balesdent, J., and Balabane, M. (1996). Major contribution of roots to soil carbon storage inferred from maize cultivated soils. Soil Biol. Biochem. 28, 1261-1263.
Sanders, J. L., and Brown, D. A. (1978). A new fiber-optic technique for measuring root growth of soybean under field conditions. Agron. J. 70, 1073-1076.

Schenk, M. K., and Barber, S. A. 1980. Potassium and phosphorus uptake by corn genotype grown in the field as influenced by root characteristics. Plant Soil 54, 65-75.

Shalhevet, J., Huck, M. G., and Schroeder, B. P. 1995. Root and shoot growth responses to salinity in maize and soybean. Agron. J. 87, 512-516.

Sharma, B. R., and Chaudhary, T. N. 1984. Nitrogen uptake by wheat in relation to water regime and depth of $\mathrm{N}$ placement in a loamy sand soil: Measurement and model simulation. J. Soil Sci. 35, 141-148.

Sharratt, B. S., and Cochran, V. L. 1993. Skip-row and equidistant-row barley with nitrogen placement; Yield, nitrogen uptake and root density. Agron. J. 85, 246-250. Welbank, P. J., and Williams, E. D. (1968). Root growth of a barley crop estimated by sampling with portable powered soil coring equipment. J. Appl. Ecol. 5, 447.

Silberbush, M., and Barber, S. A. 1984. Phosphorus and potassium uptake of field grown soybeans predicted by a simulation model. Soil Sci. Soc. Am. J. 48, 592-596.

Singh, A. K and Singh, R.S. 2012.Effect of phosphorus and bioinoculants on yield, nutrient uptake and economics of long duration pigeonpea. Indian J. Agron. 57 (3): 265-269.

Slaton, N. A., Beyrouty, C. A., Wells, B. R., Norman, R. J., and Gbur, E. E. 1990. Root growth and distribution of two short-season rice genotypes. Plant Soil 126, 269-278.

Sponchiado, B. N., White, J. W., Castillo, J. A., and Jones, P. G. 1989. Root growth of four common bean cultivars in relation to drought tolerance in environments with contrasting soil types. Exp. Agric. 25, 249-257.

Stone, L. F., and Pereira, A. L. 1994. Ricecommon bean rotation under sprinkler irrigation: Effects of row spacing, fertilization and cultivar on growth, root development and water consumption of common bean. Pesqui. Agropecu. Bras. 29, 939-954.

Stone, L. R., Goodrum, D. E., Jaafar, M. N., and Khan, A. H. 2001. Rooting front and water depletion depths in grain sorghum and sunflower. Agron. J. 93, 1105-1110.

Takenaga, H. 1995. Internal factors in relation to 
nutrient absorption. In "Science of the Rice Plant" (T. Matsuo, K. Kumazawa, R. Ishii, K. Ishihara, and H. Hirata, Eds.), Vol. 2, pp. 294309. Food and Agriculture Policy Research Center, Tokyo.

Tennant, D. 1976. Root growth of wheat. I. Early patterns of multiplication and extension of wheat roots including effects of leaves of nitrogen, phosphorus, and potassium. Aust. J. Agric. Res. 27, 183-196.

Teo, Y. H., Beyrouty, C. A., and Gbur, E. E. 1995. Evaluation of a model to predict nutrient uptake by field grown rice. Agron. J. 87, 7-12.

Thangaraj, M., O'Tolle, J. C., and De Datta, S. K. 1990. Root response to water stress in rainfed lowland rice. Exp. Agric. 26, 287-296.

Troughton, A. 1962. The roots of temperate cereals (wheat, barley, oats and rye). Mimeo-graphed Publication No. 2 Commonwealth Bureau of Pasture and Field Crops, Hurley, Berkshire.

Tupper, G. R. 1992. Technologies to solve K deficiency: Deep placement. In "1992 Proceedings of the Beltwide Cotton Production Research Conference," pp. 73-76. National Cotton Council of America, Memphis, TN.

Ueda, S. 1936. On the development of root system of wheat and barley in sandy soil. Proc. Crop Sci. Soc. Jpn. 8, 140-143.

Wahbi, A., and Gregory, P. J. 1995. Growth and development of young roots of barley (Hordeum vulgare L.) genotype. Ann. Bot. 75, 533-539.

Wang, Z.R., Rui, Y.K., Shen, J.B. and Zhang, F.S. 2008. Effect of $\mathrm{N}$ fertilizer on root growth in Zea mays L. seedlings. Spanish J. Agric. Res., 6(4): 677-682.

Welch, R. M., Allaway, W. H., House, W. A., and Kubota, J. 1991. Geographic distribution of trace element problems. In "Micronutrients in Agriculture" (J. J. Mortvedt, F. R. Cox, L. M. Shuman, and R. M. Welch, Eds.), 2nd edn., pp. 31-57. Soil Science Society of America, Madison, WI.
Werf, A. V. D. 1996. Growth analysis and photoassimilate partitioning. In "Photoassimilate Distribution in Plants and Crops" (E. Zamski and A. A. Schaffer, Eds.), pp. 1-20. Marcel Dekker, New York.

Xiaoe, Y., Romheld, V., Marschner, H., Baligar, V. C., and Martens, D. C. 1997. Shoot photosynthesis and root growth of hybrid and conventional rice cultivars as affected by $\mathrm{N}$ and $\mathrm{K}$ levels in the root zone. Pedosphere 7, 35-42.

Yamauchi, A., Kono, Y., and Tatsumi, J. 1987b. Comparison of root system structures of 13 species of cereals. Jpn. J. Crop Sci. 56, 618631.

Yibrin, H., Johnson, J. W., and Eckert, D. J. 1993. No-till corn production as affected by mulch, potassium placement, and soil exchangeable potassium. Agron. J. 85, 639-644.

Yoshida, S.(1981. Fundamentals of Rice Crop Science. IRRI, Los Bano ^s, Philippines.

Yoshida, S., and Hasegawa, S. 1982. The rice root system: Its development and function. In "Drought Resistance of Crops with Emphasis on Rice" (IRRI, Ed.), pp. 97-114. IRRI, Los Bano $\simeq$ s, Philippines.

Zhao, Z. R., Li, G. R., and Hung, G. Q. 1991. Promotive effect of potassium on adventitious root formation in some plants. Plant Sci. 79, 47-50.

Zobel, R. W. 2003. Sensitivity analysis of computer based diameter measurement from digital images. Crop Sci. 43, 583-591.

Zobel, R. W. 2005. Primary and secondary root systems. In "Roots and Soil Management: Interactions Between Roots and the Soil" (R. W. Zobel and S. F. Wright, Eds.), pp. 3-14. ASA, CSSA, and SSSA, Madison, WI.

Zobel, R. W. 2005b. Tertiary root systems. In "Roots and Soil Management: Interactions Between Roots and the Soil" (R. W. Zobel and S. F. Wright, Eds.), pp. 35-56. ASA, CSSA, and SSSA, Madison, WI.

\section{How to cite this article:}

Sathiyavani, E., N.K. Prabaharan and Krishna Surendar, K. 2017. Role of Mineral Nutrition on Root Growth of Crop Plants - A Review. Int.J.Curr.Microbiol.App.Sci. 6(4): 2810-2837. doi: https://doi.org/10.20546/ijcmas.2017.604.324 